\title{
Natural Rights, Natural Law, and American Constitutions
}

\author{
Philip A. Hamburger ${ }^{\dagger}$
}

[T] he First Amendment ... does not forbid the abridging of speech. But, at the same time, it does forbid the abridging of the freedom of speech. It is to the solving of that paradox, that apparent selfcontradiction, that we are summoned if, as free men, we wish to know what the right of freedom of speech is.

-Alexander Meiklejohn ${ }^{1}$

Nature, like Liberty, is but restrained

By the same laws which first herself ordained.

-Alexander Pope ${ }^{2}$

\section{INTRODUCTION}

Natural rights and natural law are ideas that frequently seem to have something in common with the elusive shapes of a Rorschach test. They are suggestive of well-defined, recognizable images, yet they are so indeterminate that they permit us to see in them what we are inclined to see. Like Rorschach's phantasm-inducing ink blots, natural rights and natural law are not only suggestive but also indeterminate-ideas to which each of us can plausibly attribute whatever qualities we happen to associate with them. For this reason, we may reasonably fear that natural rights and natural law are ideas often used to legitimate what are, in fact, our individual preconceptions and desires.

Many scholars have discussed natural law and natural rights, and often they have employed these ideas to claim the existence of unwritten constitutional rights or to claim that constitutional rights should be expansively defined. For example, some notable academics, including Edward S. Corwin, Bernard Bailyn,

$\dagger$ Professor of Law and Legal History, National Law Center, George Washington University. B.A. 1979, Princeton University; J.D. 1982, Yale Law School. The author gratefully acknowledges the generous financial support of the Lynde and Harry Bradley Foundation and the helpful suggestions of Jerome A. Barron, Walter Bems, Thomas C. Dienes, Miriam Galston, Michael T. Gibson, Richard S. Kay, Thomas A. McAffee, Beth Nolan, and Arthur E. Wilmarth, Jr.

1. AleXander MeIKlejohn, POLITICAL Freedom: The Constitutional Powers of the PEOple 21 (1965).

2. ALEXANDER POPE, AN ESSAY ON CRTTICISM 64 (London, MacMillan 1925) (1711) (bk. 1, 11. 90-91). 
Gordon S. Wood, Thomas C. Grey, Suzanna Sherry, and Randy E. Barnett, have argued that in the 1780's and 1790's natural law and natural rights were vaguely considered sources or authority for unwritten constitutional rights. ${ }^{3}$ Moreover, some of these scholars, as well as others, assume that natural rights and natural law implied a relatively unconstrained degree of liberty. ${ }^{4}$

In the eighteenth century, however, American ideas of natural rights and natural law were neither so indefinite nor so expansive. ${ }^{5}$ It will be seen that natural rights and natural law were ideas that were relatively precisely defined and that were understood to imply a broad but also substantially limited degree of liberty.

This Article will make five arguments concerning the limited extent of natural rights. First, natural rights were circumscribed by their very character as natural rights. Natural liberty was the undifferentiated freedom individuals had in the state of nature or the absence of government, and a natural right was simply a portion of that more general liberty. By definition, therefore, natural rights did not conventionally include acquired rights-rights existing only under civil government. For example, freedom of speech or of the press was a right that could be exercised in the absence of government and therefore was considered a natural right, whereas the right of a sheriff to retain his position, notwithstanding his political views, could only be had under government and therefore was distinguished as an acquired right.

Second, not only were natural rights distinguished from acquired rights but also they were understood to be subject to natural law. Natural law ordinarily was held to consist of reasoning-reasoning about how humans should use or enjoy their natural liberty. For example, an individual in the state of nature, Americans assumed, should reason that, in ordinary circumstances, he could most efficaciously preserve his natural liberty by voluntarily not doing to others

3. See BERNARD BAILYN, THE IDEOLOGICAL ORIGINS OF THE AMERICAN REVOLUTION (1967); GORDON S. WOOD, THE CREATION OF THE AMERICAN REPUBLIC, 1776-1787 (1969); Randy E. Bamett, Introduction: James Madison's Ninth Amendment, in THE RIGHTS RETAINED BY THE PEOPLE 1, 33-34 (Randy E. Bamett ed., 1989); Edward S. Corwin, The "Higher Law" Background of American Constitutional Law, 42 HARV. L. REv. 149 (1928); Thomas C. Grey, Origins of the Unwritten Constitution: Fundamental Law in American Revolutionary Thought, 30 STAN. L. REV. 843 (1978); Thomas C. Grey, Do We have an Unwritten Constitution?, 27 STAN. L. REv. 703 (1975) [hereinafter Grey, Do We Have an Unwritten Constitution?]; Calvin R. Massey, Federalism and Fundamental Rights: the Ninth Amendment, in THE RIGHTS RETAINED BY THE PEOPLE, supra, at 291, 318-31; Bennett B. Patterson, The Forgotten Ninth Amendment, in THE RIGHTS RETAINED BY THE PEOPLE, supra, at 107; Suzanna Sherry, The Founders' Unwritten Constitution, 54 U. CHI. L. REV. 1127 (1987); Eugene M. Van Loan, III, Natural Rights and the Ninth Amendment, in THE RIGHTS RETAINED BY THE PEOPLE, supra, at 149, 162-63.

4. Suggestions about the expansive implications of natural rights can be found in some of the arguments that natural rights are a form of unwritten constitutional law. See, e.g., Massey, supra note 3, at 291, 318-19, 321-31; Patterson, supra note 3, at 107; Van Loan, supra note 3, at 149, 162-63. Another context in which such suggestions may be found is the dispute as to whether the freedom of speech and press is an absolute right. See infra note 8 and accompanying text.

5. Of course, when discussing "American" ideas of natural rights or what "Americans" assumed about natural rights, this Article will be making assertions, not about all Americans, but about those Americans who discussed or otherwise analyzed natural rights. See infra text accompanying notes 22-29. 
what he would not have them do to him-that he typically could preserve himself by not injuring others. Thus, already in the state of nature, an individual's natural freedom was constrained by the implications of natural law-by his capacity to reason about his natural liberty and about the means of preserving it.

Third, under civil government-that is, under secular government and its legal system-natural liberty was available only as permitted by civil law. To protect themselves and their natural liberty from those who did not conform to the law of nature, individuals in the state of nature, Americans said, sought the protection of government. In particular, the people adopted a constitution in which they submitted some of their natural liberty to government in order to obtain the protection of government and its laws for the remainder. As a result, natural rights, including the natural right of free speech and press, were retained under civil government only to the extent permitted by the constitution and other civil laws.

Fourth it will be seen that civil law was expected to reflect natural law. In other words, civil law was expected to adopt and enforce rules that approximated the constraints implied by natural law.

Fifth, if civil laws generally reflected natural law, and if, as noted above, natural liberty was understood to be subject to natural law, then there was no tension or inconsistency between a natural right and the civil laws regulating it. In this way, the civil laws punishing defamation and fraud, for example, could be described as compatible with the natural right of free speech and press.

\section{A. Significance}

These arguments about the limits on natural rights can reconcile what might otherwise appear to be a conflict between the requirements of positive law and the expansive implications of natural law and natural rights. As mentioned above, Professors Corwin, Bailyn, Wood, Grey, Sherry, and Barnett have argued that late eighteenth-century Americans typically understood fundamental or constitutional law to include natural law and that such Americans therefore considered natural law a source of unwritten constitutional rights. ${ }^{6}$ In response, other scholars, including Professors Walter Berns and Helen K. Michael, have contended that Americans typically did not confuse natural law and constitutional law, and that Americans tended to understand the Constitution to consist of the written document. ${ }^{7}$ This Article will present new evidence strongly supporting

6. See supra note 3 .

7. See RONALD M. PETERS, JR., THE MASSAChUSETtS CONSTTTUTION OF 1780: A SOCIAL COMPACT 1-13 (1978); Walter Berns, Judicial Review and the Rights and Laws of Nature, 1982 SUP. CT. REV. 49; Helen K. Michael, The Role of Natural Law in Early American Constitutionalism: Did the Founders Contemplate Judicial Enforcement of "Unwritten" Individual Rights?, 69 N.C. L. REV. 421 (1991). For an important discussion of related issues, see Thomas B. McAffee, The Original Meaning of the Ninth Amendment, 90 CoLUM. L. REV. 1215 (1990) (arguing that Ninth Amendment was understood to protect 
the latter view, that natural law was typically understood in the late eighteenth century to have a role quite different from that of constitutional law. Indeed, the Article will show that natural law was understood to explain the necessity of written constitutions. Yet it will also show that natural law was assumed to have a role in constitutional analysis - a role that historians and lawyers have thus far ignored.

Another example of how this inquiry regarding the limits on natural rights can harmonize apparent conflicts in constitutional theory may be observed in the regulation of natural rights. Some judges and scholars have insisted that the freedom of speech and press and the other natural rights protected by the Bill of Rights have "absolute" guarantees in the Bill of Rights and therefore cannot constitutionally be restrained by government. ${ }^{8}$ Other commentators, however, have pointed out that such rights have always been subject to some legal restraints. ${ }^{9}$ Can laws restrain or otherwise regulate rights without infringing them? ${ }^{10}$ Although this Article can hardly provide a definitive solution to this difficulty, it will suggest one of the ways Americans addressed the problem at the time of the writing of our Constitution.

The significance of the limits on natural rights can be illustrated most dramatically if we focus now in considerable detail on a third issue, the freedom of speech and press. ${ }^{11}$ Although historians have long recognized that freedom of speech and press was considered a natural right, they have not pursued the significance of this classification. ${ }^{12}$ As will become evident, the natural rights analysis can illuminate the historical definition of the constitutional right of freedom of speech and press. In particular, the limits on natural rights implied by that analysis can resolve some apparent contradictions or paradoxes.

The freedom of speech and press-or almost any other natural right-can seem unsystematic, contradictory, and even paradoxical. Prior to 1798, almost

rights merely by preventing misconstruction of written Constitution's scheme of limited federal powers); Arthur E. Wilmarth, The Original Purpose of the Bill of Rights: James Madison and the Founders' Search for a Workable Balance between Federal and State Power, 26 AM. CRM. L. REV. 1261 (1989) (arguing that Bill of Rights was understood to preserve balance between federal and state powers).

8. This dispute was most prominently apparent in Konigsberg v. State Bar, 366 U.S. 36, 49-56 (1961); id. at 56-80 (Black, J., dissenting); Dennis v. United States, 341 U.S. 494, 524 n.5 (1950) (Frankfurter, J., concurring); Hugo L. Black, The Bill of Rights, 35 N.Y.U. L. REv. 865 (1960); Harry Kalven, Jr., The New York Times Case: A Note on "The Central Meaning of the First Amendment," 1964 SUP. CT. REV. 191; Alexander Meiklejohn, The First Amendment is an Absolute, 1961 SuP. CT. REV. 245 [hereinafter Meiklejohn, Absolute]; see also, e.g., JOHN E. NOWAK ET AL., CONSTITUTIONAL LAW 865-67 (2d ed. 1983).

9. See sources cited supra note 8 .

10. This analysis is particularly common with respect to the right of property and the Takings Clause. Another solution has been to define a right, such as freedom of speech, narrowly in terms of the historical common law right-that is, for example, in terms of the laws of defamation, obscenity, and fraud, etc. See, e.g., the discussion infra notes $14-15$ \& 113 and accompanying text.

11. Generalizations about natural rights often seem more abstract than informative. Therefore, this Article will illustrate the late eighteenth-century natural rights theory with a concrete example, the freedom of speech and press. By studying this right in its context as a natural right, we can clarify eighteenth-century abstractions about natural rights and, conversely, can learn about the freedom of speech and press.

12. See infra notes 14-16 and accompanying text. 
all Americans who asserted the right of free speech and press did not argue that they were, on that basis, free from the laws regulating seditious libel, other types of defamation, obscenity, or fraud. Nor did these Americans object to myriad laws distributing acquired rights, such as, for example, government employment, on the basis of the recipient's political opinions. To historians, the instances in which these eighteenth-century Americans accepted limitations on speech and press have sometimes seemed contradictory, unsystematic, and arbitrary. ${ }^{13}$

Attempting to resolve some of these contradictions, Professor Leonard W. Levy has argued that late eighteenth-century Americans adhered to the "common law" definition of freedom of the press-that they understood freedom of the press to be defined by the traditional common law restraints upon the press, including seditious libel prosecutions. ${ }^{14}$ Yet, as will be seen below, Americans did not always employ so narrow a definition-indeed, some discussed a freedom to speak and publish as one pleases, a freedom that was restrained rather than defined by seditious libel prosecutions. Moreover, as Levy himself has suggested, even the common law definition of freedom of the press merely provided a doctrinal solution to the problem. Reflecting a frequent assumption that, at a more general or theoretical level, eighteenth-century Americans were being contradictory, Levy has observed that "[ $[$ ] $]$ he theory of free political expression as a natural right and the concept of seditious libel could not forever coexist."15 Thus, although Levy shows that the doctrine of seditious libel was considered to be consistent with the freedom of the press, he recognizes that the natural right of freedom of speech and press was not always defined in terms of seditious libel or other common law doctrines. ${ }^{16}$ In sum, Levy's solution to

13. See infra notes 14-20 \& 139-143 and accompanying text

14. LEONARD W. LEVY, EMERGENCE OF A FREE PRESS (1985). Levy's thesis has been challenged on the ground that eighteenth-century newspapers actually printed a wide range of opinion highly critical of govemment and on the basis of a relatively small number of writings, dating from the late 1780's and the early 1790's, rejecting the law of seditious libel as contrary to the right of freedom of speech and press. See, e.g., David A. Anderson, The Origins of the Free Press Clause, 30 UCLA L. REv. 455 (1983). Interesting as these arguments are, however, they do not undermine Levy's fundamental point that, in the early 1790's, seditious libel prosecutions typically were not considered incompatible with the freedom of the press.

15. LEVY, supra note 14, at 117. Commenting on this traditional perception of an historical contradiction between the principle and the restraints upon it, Professor Robert Palmer has noted: "The debate ... thus far has treated the First Amendment as embodying an ideology, as being a principle. Historians following that approach, whatever their ultimate conclusions, have all found it necessary to delineate the areas in which the eighteenth century considered the kinds of speech or press activities so abominable as to fall outside legitimate rights' protections." Palmer then attempts to resolve this tension by asserting that the "first amendment freedom of press" was "a right that was purposely unreasonable and unprincipled." Robert C. Palmer, Liberties as Constitutional Provisions 1776-1791, in LIBERTY AND COMMUNITY: CONSTITUTION AND RIGHTS IN THE EARLY AMERICAN REPUBLIC 55, 56-57 (William E. Nelson \& Róbert C. Palmer eds., 1987). See also IRVING BRANT, THE BILL OF RIGHTS: ITS ORIGN AND MEANING 223-36 (1965) (arguing that, in absence of enumerated federal power over press, First Amendment forbids Congress from making laws abridging speech or press).

Incidentally, there is relatively little scholarship on the idea of freedom of speech and press in the nineteenth century. But see Michael T. Gibson, The Supreme Court and Freedom of Expression From 179 I to 1917, 55 FORDHAM L. REV. 263 (1986).

16. Levy does not directly address this issue, perhaps, in part, because he focuses on freedom of the press rather than freedom of speech and suggests that freedom of the press was not considered a natural 
the free speech paradox is important, but it also is incomplete, because it does not even purport to explain how eighteenth-century Americans reconciled their highly restrictive laws with their claim that the freedom of speech and press was a natural right.

For modern lawyers, this contradiction amounts to a paradox at the heart of the constitutional right of freedom of speech and press. For example, after reminding his readers of the late eighteenth-century law of defamation, Professor Alexander Meiklejohn concluded that "these necessities that speech be limited" were "not unknown to the writers of the First Amendment" and were "recognized and provided for under the Constitution." Thus, the First Amendment "does not forbid the abridging of speech," and yet, "at the same time, it does forbid the abridging of the freedom of speech." This was, said Meiklejohn, a "paradox" or "apparent self-contradiction" we must somehow address. ${ }^{17}$ The assumption that there is a contradiction also turns up in modern judicial opinions that employ a balancing test or otherwise assume a conflict between the principle or generality of free speech and the various traditional laws restraining speech. ${ }^{18}$ On the basis of this apparent tension or conflict, the Supreme Court has cut down large swaths of traditional law regulating "expression," retaining only such restraints as it considers indispensable, ${ }^{19}$ and it has extended the right of free

right. See LEVY, supra note 14, at 224.

17. MEIKLEJOHN, supra note 1, at 21 (emphasis omitted). So too, for example, Professor Ronald Dworkin has noted the "conflict between the rights of a particular speaker as an individual and the competing interests of the community as a whole." Ronald Dworkin, Is the Press Losing the First Amendment?, N.Y. REv. Books, Dec. 4, 1980, at 52, quoted in William T. Mayton, Seditious Libel and the Lost Guarantee of a Freedom of Expression, 84 CoLUM. L. REV. 91, 93 (1984). Professor Thomas Emerson began his book on the First Amendment by noting his regret that "no really adequate or comprehensive theory of the First Amendment has been enunciated." He added that "[p]roponents of the 'absolute' or 'literal' interpretation of the First Amendment have failed to define the bounds of their position or to account for such apparent exceptions to the absolute test as the law of libel. ... . Their views have therefore been dismissed as impractical or illogical, or both." THOMAS. I. EMERSON, TOWARD A GENERAL THEORY OF THE FIRST AMENDMENT, at vii (1966). See also THOMAS I. EMERSON, THE SYSTEM OF FREEDOM OF EXPRESSION 517 (1970) (arguing that Constitutional freedom of expression is limited by libel and privacy law, which seeks to protect individual and private interests); WILLIAM W. VAN ALSTYNE, INTERPRETATIONS OF THE FIRST AMENDMENT 21-49 (1984) (discussing differing approaches to First Amendment interpretation and unprotected speech); J.L. Merin, Libel and the Supreme Court, 11 WM. \& MARY L. REV. 371 (1969) (condemning contemporary Supreme Court for moving toward absolutist interpretation of First Amendment).

By addressing this paradox, this Article will also suggest an explanation of the use of the word "abridge" rather than "prohibit" with respect to free speech and press in the First Amendment to the U.S. Constitution. See infra text accompanying note 99.

18. See, e.g., Curtis Publishing Co. v. Butts, 388 U.S. 130, 152 (1967) (Harlan, J.) ("[S]ome antithesis between freedom of speech and press and libel actions persists, for libel remains premised on the content of speech and limits the freedom of the publisher to express certain sentiments, at least without guaranteeing legal proof of their substantial accuracy."); see also Ollman v..Evans, 750 F.2d 970, 993 (D.C. Cir. 1984) (Bork, J., concurring) (discussing difficulty of resolving "the sometimes contradictory claims of the libel laws and the freedom of the press"). These concerns are apparent in the old dispute-between Justices Black and Harlan and between Professors Meiklejohn and Kalven, among others-as to whether the freedom of speech and press is an "absolute" right or merely a right defined by a balancing of competing interests. See supra note 8.

19. See, e.g., Miller v. California, 413 U.S. 15 (1973) (obscenity); Rosenbloom v. Metromedia, Inc., 403 U.S. 29 (1971) (civil action for defamation brought by private individual); Curtis Publishing Co. v. Butts, 388 U.S. 130 (1967) (civil action for defamation brought by public figure); Garrison v. Louisiana, 379 U.S. 64 (1964) (criminal prosecution for defamation of judges); New York Times v. Sullivan, 376 U.S. 254 (1964) 
speech to require that government sometimes not take speech into account when distributing or denying what eighteenth-century Americans typically considered to be acquired rights. ${ }^{20}$

But are we necessarily confronted with a paradox? Could it be a problem of our own making? By examining freedom of speech and press in the framework of broader ideas about natural rights, this inquiry will question whether the tensions and contradictions we perceive were, in fact, characteristic of late eighteenth-century ideas of free speech and press. There is, this Article suggests, an historical alternative to our modern assertions that freedom of speech is in tension with the laws restraining speech. Late eighteenth-century Americans typically assumed that natural rights, including the freedom of speech and press, were subject to natural law and that the laws of defamation, obscenity, and fraud reflected natural law. Therefore, eighteenth-century Americans tended to take for granted that such laws were consistent with the natural right of freedom of speech and press.

These older ideas about freedom of speech and press-so different from those which prevail today-illustrate the significance of the eighteenth-century natural rights analysis for our understanding of modern constitutional rights. If some of the apparent contradictions in eighteenth-century law reflect our flawed understanding of eighteenth-century Americans rather than their flawed logic, then what appear to be their contradictions can, perhaps, lead us to a better understanding of our own.

(civil action for defamation brought by government officials); Roth v. United States, 354 U.S. 476 (1957) (obscenity). Justice Black went so far as to say that "libel laws are abridgements of speech and press and therefore are barred in both federal and state courts by the First and Fourteenth Amendments." Rosenblatt v. Baer, 383 U.S. 75, 95 (1966) (Black, J., concurring).

20. See Rutan v. Republican Party of Ml., 479 U.S. 62 (1990) (concerning promotion, transfer, recall, and hiring); Rankin v. McPherson, 483 U.S. 378, 381 (1987) (deputy constable may nat be fired for saying of President Reagan, "[i]f they go for him again, I hope they get him"); Branti v. Finkel, 445 U.S. 507 (1980) (threat of discharge); Elrod v. Bums, 427 U.S. 347 (1976) (govemment officials may not discharge public employees solely for supporting political party in power, unless party affiliation is an appropriate requirement for position involved); Pickering v. Board of Education, 391 U.S. 563 (1968) (public school teacher may not be dismissed for speech critical of Board of Education if such speech does not impede teacher's performance of duties or interfere with operation of schools generally). So too, the right to have books retained in public and public school libraries has been widely recognized. See, e.g., Board of Education v. Pico, 457 U.S. 853 (1982); Minarcini v. Strongville City Sch. Dist., 541 F.2d 577 (6th Cir. 1976); Sheck v. Baileyville Sch. Comm., 530 F. Supp. 679 (D. Me. 1982); Savail v. Nashua Bd. of Educ., 469 F. Supp. 1269 (D. N.C. 1979); But see Rust v. Sullivan, 111 S. Ct. 1759 (1991) (government does not unconstitutionally discriminate on basis of viewpoint when it subsidizes family planning clinics that favor childbirth over abortion but denies subsidies to programs that provide abortion counseling). 


\section{B. Methodology and Evidence ${ }^{21}$}

If we are to examine the role of natural rights in late eighteenth-century American constitutional analysis, and, in particular, if we are to elucidate American ideas about limits on natural rights, we must attempt to reconstruct some of the widely-held theoretical assumptions that provided the context for American discussions of these subjects. Therefore, this Article cannot simply examine the writings of Madison, Jefferson, and the half-dozen others whose views are the focus of so much historical study. Although the writings of these eminent Americans are of great importance and deserve the careful study they have received, they constitute only part of the evidence relevant to the question asked here. To learn more generally about late eighteenth-century American natural rights theory, we will have to reconstruct the common assumptions of a much larger number of Americans. For example, when an eighteenth-century American, whether prominent or obscure, mentioned, without explanation, that freedom of speech was a natural right, he probably took for granted that his audience shared at least some of his assumptions about natural rights. ${ }^{22}$ It is precisely his unexplained assumptions-his assumptions that he did not think required explanation-that we need to explore.

The assumptions Americans frequently took for granted in their discussions of natural rights are a fruitful object of inquiry because many Americans appear, indeed, to have shared some such assumptions. Whereas much scholarship has disputed the relative "influence" on Americans of the varying ideas espoused by Locke, Sidney and other European writers, ${ }^{23}$ this Article, in contrast, emphasizes that Americans, nonetheless, often extracted highly generalized notions from the works of these authors. ${ }^{24}$ At least for purposes of political

21. Two bibiliographic points must be made about the sources used in this Article. First, the Article relies heavily upon eighteenth-century publications. To the extent they have survived, they are available on microfiche produced by the American Antiquarian Society and are usually referred to here by their "Evans" numbers. See NATIONAL INDEX OF AMERICAN IMPRINTS THROUGH 1800; THE SHORT-TITLE EVANS (Clifford K. Shipton et al. eds., 1969).

Second, many essayists of the eighteenth century wrote under pseudonyms. In this Article, when the author of a cited work used a pseudonym, it will be put in quotation marks, and the author's true name, if known, will be placed in brackets. If there is gond, but not probative, evidence concerning the pseudonymous author's true name, that name will be placed in brackets with a question mark.

22. This is not a point eighteenth-century Americans were apt to address directly. For some suggestive remarks, however, see the comments of William Welsteed, infra note 31; Samuel Webster, infra note 37; William Pierce and Nathaniel Chipman, infra note 70; the "Impartial Examiner," infra note 78; Thomas Reese, infra note 88.

23. See, e.g., DONALD LUTZ, THE ORIGINS OF AMERICAN CONSTITUTIONALISM 114 (1988) (emphasizing influence of Sidney); John Dunn, The Politics of Locke in England and America in the Eighteenth Century, in JOHN LOCKE: PROBLEMS AND PERSPECTIVES 45 (John W. Yolton ed., 1969) (disparaging influence of Locke); Isaac Kramnick, Republican Revisionism Revisited, 87 AM. HIST. REV. 629 (1982) (challenging disparagement of influence of Locke in England).

24. Although the dispute about which writer was more influential is not unimportant, this debate should not obscure the degree to which so much American natural rights analysis refiected a shared, generalized approach. The arguments of Pufendorf were among the most scholarly of many that employed a common vocabulary and mode of analysis. In popularizing a succinct, generally stated, and attractive version of the 
discourse, Americans tended to reduce various European theories to their common components. Of the Americans who attended school, some became knowledgeable about the ideas espoused by particular European theorists; ${ }^{25}$ a much larger number of Americans, however, only became familiar with - or only retained-a relatively simple approach abstracted from the details of the foreign treatises. This simplified, generalized theory that Americans often learned in school, they repeated and had reinforced in sermons and secular political arguments. ${ }^{26}$ It is hardly surprising, therefore, that large numbers of Americans spoke about government, liberty and constitutional law on the basis of some shared assumptions about natural rights and the state of nature. ${ }^{27}$ Of course,

state-of-nature analysis, the briefer works of Hutcheson and Pufendorf were particularly important. Incidentally, their writings undermine the assumption of some American historians, such as Bernard Bailyn, that the analysis was peculiarly novel, American, and revolutionary. See, e.g., BAIlYN, supra note 3, at 175-89.

25. Americans who attended grammar school and, particularly, college-whether in England or America-typically had a substantial part of their education in ethics, jurisprudence and politics from the treatises of Pufendorf and various other exponents of a natural rights or state-of-nature analysis. ANNA HADDOW, POLITICAL SCIENCE IN AMERICAN COLLEGES AND UNIVERSITIES 1636-1900, at 3-100 (1969). The use of natural rights analysis and the ideas associated with it may be observed in the annual theses and quaestiones of various colleges, including Harvard and Yale. For a Princeton lecture based on natural rights theory, see JOHN WITHERSPOON, AN ANNOTATED EDITION OF LECTURES ON MORAL PHILOSOPHY 122-28 (Lecture X) (Jack Scott ed., 1982) (published 1800-01; composed 1768). See also Philip A. Hamburger, The Development of the Nineteenth Century Consensus Theory of Contract, 7 LAW \& HIST. REV. 241, 306-07, nn.125-28 (1989) and works cited therein.

When explaining why the U.S. Constitution should not be prefaced with a general pronouncement about natural equality and the reasons for establishing government, Randolph pointed out, among other things, that such matters were "fitter for the schools." SUPPLEMENT TO MAX FARRAND's THE RECORDS OF THE FEDERAL CONVENTION OF 1787, at 183 (James H. Hutson ed., 1987) [hereinafter SUPPLEMENT TO FARRAND]. In the Federalist, Hamilton said such preambles "would sound much better in a treatise of ethics than in a constitution of government." THE FEDERALIST NO. 84, at 513 (Alexander Hamilton) (Clinton Rossiter ed., 1961).

26. When concluding his moral philosophy lectures at Princeton, John Witherspoon told his students: "[E]ach of the divisions we have gone through might have been treated at far greater length. Nor would it be unprofitable to enter into a fuller disquisition of many points; but this must be left to every scholar's inclination and opportunities in future life." WITHERSPOON, supra note 25, at 186 (Recapitulation). For an example of his approach, see his comments on whether the state of nature was a state of war. Id. at 122-23 (Lecture X). The simplification of the theory to avoid what seemed to be unnecessarily refined and fruitless distinctions occurred not only in American schools, but also and more emphatically in American political debates, as will be apparent throughout this Article.

Simplification and generalization of the natural rights analysis had already been common in England. For example, Locke's friend, James Tyrrell, wrote: "I shall not trouble myself to defend the manifold distinctions, and contradictions of the old Civil Lawyers about the Law of Nature, and the Law of Nations; or whether the natural, and Moral law be all one, it is sufficient if Grotius's definition of the Law of Nature be true ... " JAMES TYRRELL, PATRIARCHA NON MONARCHA 137 (1681). Blackstone said of the dispute conceming vesting of property that it was "[a] dispute that savours too much of nice and scholastic refinement! However, both sides agree in this, that occupancy is the thing by which the title was in fact originally gained ...." 2 WILlIAM BLACKSTONE, COMMENTARIES *8. See also Andrew Tooke, To the Reader, in SAMUEL PUFENDORF, THE WHOLE DUTY OF MAN (Andrew Tooke trans., 1716) (translator's preface); THOMAS RUTHERFORTH, INSTTTUTES OF NATURAL LAW 5 (2d ed. 1832) (1754) (bk. I, ch. 1, § 6).

27. On the importance of natural rights or state-of-nature analysis, see, e.g., PETERS, supra note 7 , at 1-13, 225-27; Berns, supra note 7, at 49; Rozann Rothman, The Impact of Covenant and Contract Theories on Conceptions of the U.S. Constitution. PUBLIUS, Fall 1980, at 149. See also Kramnick, supra note 23, at 87 (focusing chiefly on England). In contrast, Wood and Bailyn have deprecated the importance of the state-of-nature or natural rights analysis. See generally BAILYN, supra note 3, at ch. 2; WoOD, supra note 3. Even Bailyn, however, concedes: "In pamphlet after pamphlet the American writers cited Locke on natural rights and on the social and govemmental contract,... Grotius, Pufendorf, Burlamaqui, and Vattel on the laws of nature and nations and on the principles of civil government." BAllYN, supra note 3, at 27. As will 
many Americans did not use the natural rights analysis, and, therefore, when examining the views of "Americans," this Article can only refer to those Americans who discussed natural rights and natural law, who followed such discussions, or who otherwise reflected upon the subject. Although these hardly were all Americans or necessarily representative Americans, and although Americans also used other modes of analyzing law, Americans who employed natural rights analysis did so on the basis of some more or less common assumptions. Varied types of Americans, including the sophisticated and the simple, the laconic and the long-winded, employed versions of a single mode of analysis, ${ }^{28}$ and two centuries later we must examine their common assumptions about that analysis-we must study their common intellectual context-if we are to understand what they said about natural rights. ${ }^{29}$

To reconstruct American assumptions about natural rights, this Article will rely upon the relatively discursive writings in which Americans explained these assumptions, including a type of publication somewhat neglected by historians of law: the eighteenth-century election sermons of Congregational New England. ${ }^{30}$ Many historians of constitutional theory have discussed eighteenth-

be seen below, this Article dissents from Wood and Bailyn not only on the importance of the natural rights analysis but also on its relation to written constitutions.

28. See PETERS, supra note 7, at 225-27. As ane might expect, Americans employed different versions of the analysis, and they could use any one version for disparate purposes and with varying degrees of sophistication. Some of this variety will be illustrated below, but it is the analysis shared by large numbers of Americans that is the focus of this discussion.

29. Eighteenth-century Americans sometimes discussed the extent of their differences. Carter Braxton-a Virginia planter and, at varying times, a member of the Continental Congress and the Virginia Assembly - wrote: "Although all writers agree in the object of government, and admit that it was designed to promote and secure the happiness of every member of society, yet their opinions, as to the systems most productive of this general benefit, have been extremely contradictory." "A NATIVE OF THIS COLONY" [CARTER BRAXTON], AN ADDRESS TO THE CONVENTION OF THE COLONY AND ANCIENT DOMINION OF VIRGINIA (1776), reprinted in 1 AMERICAN POLITICAL WRITING DURING THE FOUNDING ERA 1760-1805 at 330 (Charles S. Hyneman \& Donald S. Lutz eds., 1983) [hereinafter AMERICAN POLTICAL WRITING]. As even Braxton conceded, there was a consensus on at least some general points. For example, many Americans disagreed as to whether the state of nature was a state of war or merely of inconvenience; similarly, many disagreed as to whether man was a "social" being. Nonetheless, the vast number of Americans who discussed the creation of government tended to agree upon some important matters, such as that individuals established government in order to protect their natural rights from whatever degree of hazard or inconvenience existed in the state of nature. Although some Americans considered a constitution to be a declaration or act of the people rather than a contract, this alternative description of a constitution was often in accord with other aspects of the contract theory. Notwithstanding the fact that the Charleston lawyer, Timothy Ford, said that "such a state as is called a state of nature never in fact existed" and was a "fairy tale," he employed much of the rest of the theory. "Americanus" [Timothy Ford], The Constitutionalist: Or, An Inquiry How Far It Is Expedient and Proper to Alter the Constitution of South Carolina, CITY GAZ. AND DAILY ADVERTZER (1794), reprinted in 2 AMERICAN POLITICAL WRITING, supra, at 902. Moreover, he observed that "[i]t has been customary amongst theoretical writers on government, to deduce the rights of man from an ideal state, called a state of nature." Id. at 900 .

30. On the importance of election sermons for the dissemination of such ideas, see Arthur W. Plumstead, Introduction to THE WALL AND THE GARDEN: SELECTED MASSACHUSETTS ELECTION SERMONS, 1670-1775, at 3-44 (Arthur W. Plumstead ed., 1968) [hereinafter THE WALL AND THE GARDEN]; 2 THE PURITAN SERMON IN AMERICA. 1630-1750, at v-xlvi (Ronald A. Bosco ed., 1978). Writing of an earlier period, Perry Miller said that the election sermon was "the most important single form of publication concemed with the theory of society." THE PURITANS 792 (Perry Miller and Thomas H. Johnson eds., 1938), quoted in THE WALL AND THE GARDEN, supra, at 14. For a notable selection of later sermons, see POLIICAL SERMONS OF THE 
century political essays, debates, and letters. This inquiry, however, will also draw upon election sermons-and not for their account of religion.

Election sermons contained a wealth of rather conventional political theory. One Connecticut minister began an election sermon on divine government by explaining that civil government had been "so often, and so well treated of upon such Occasions as this; that it is needless to add any thing . . . on this Subject."31 From another point of view, the polemical Dean of Gloucester worried about the influence of American ministers and complained of "their preferring and inculcating principles of Mr. Lock instead of the Gospel, relative to the original titles of civil governors." ${ }^{32}$ Of course, the political sermons that troubled some contemporaries are today a blessing, and no less so for their relative unoriginality-for their tendency to elaborate commonly-held assumptions about natural rights. The political theory preached to a captive audience of legislators and state officials is interesting today largely because it once was platitudinous.

This Article's frequent reliance upon election sermons, however, should not be assumed to indicate that the ideas examined here were exclusively the product of New England Congregationalists. ${ }^{33}$ Put another way, the superabundance of evidence from one group of persons is not evidence that others, less fecund in their publications, held contrary assumptions. Indeed, evidence from persons of disparate political and religious opinions and from widelyseparated regions are cited here. Notwithstanding the fact that they left different amounts of evidence, Congregationalists and Baptists, Federalists and AntiFederalists, Southerners and Northerners, all could use the natural rights analysis and, even while developing different versions of that analysis, ${ }^{34}$ they appear to have drawn upon certain shared assumptions. ${ }^{35}$ It is this foundation of shared assumptions about natural rights and natural law that will be examined here.

AMERICAN FOUNDING ERA 1730-1805 (Ellis Sandoz ed., 1991) [hereinafter POLITCAL SERMONS].

31. PETER REYNOLDS, THE KINGDOM IS THE LORD'S 5 (Conn. election sermon 1757) (Evans 8017). A Massachusetts minister hoped that "the religious solemnities" of election days "never degenerate into a . . cold and lifeless Harangue upon Politicks." WILLIAM WELSTEED, THE DIGNTYY AND DUTY OF THE CIVL MAGISTRATE 28 (Mass. election sermon 1751) (Evans 6793), cited in THE WALL AND THE GARDEN, supra note 30, at 35. See also ALICE M. BALDWI, THE NEW ENGLAND CLERGY AND THE AMERICAN REVOLUTION 6 (1928).

32. JOSIAH TUCKER, A SERIES OF ANSWERS TO.CERTAIN POPULAR OBJECTIONS AGAINST SEPARATING FROM THE REBELLIOUS COLONIES, AND DISCARDING THEM ENTIRELY (1775) (advertisement, opposite title, for forthcoming pamphlet) (on file with author). According to the Loyalist Peter Oliver, "[t]he Clergy had quite unlearned the Gospel, \& had substituted Politicks in its Stead." PETER OLIVER, ORIGIN \& PROGRESS OF THE AMERICAN REVOLUTION 148 (1781), quoted in BALDWIN, supra note 31, at 122 n.1.

33. Even election sermons could come from persons of very different views. Among the election sermons cited here are two by Baptists, Caleb Blood and Samuel Stillman, and one by an Anglican, John Cozens Ogden.

34. Such variations were, for some purposes, very significant. Of particular interest here, some religious groups and some less educated social groups appear to have used the natural rights analysis less frequently and with less sophistication than others. Yet these variations need not be traced in this Article, the purpose of which is simply to explicate the general outline of the analysis. it.

35. Probably each individual who employed the theory had his own, somewhat different version of 


\section{NATURAL RIGHTS}

Some well-known scholars have examined American ideas about natural rights. ${ }^{36}$ Nonetheless, for purposes of this Article, it is necessary to pursue the subject a little further by focusing on what was not a natural right. We should hardly be surprised to find that some rights enumerated in American bills of rights were said to be natural rights and some were not - that natural rights were distinguished from acquired rights.

In the 1780's and early 1790's, Americans occasionally specified which of their rights were natural rights and which were not, and they tended to agree in their characterizations. On the assumption that the state of nature was a condition in which all humans were equally free from subjugation to one another-in which individuals had no common superior-Americans understood natural liberty to be the freedom of individuals in the state of nature. ${ }^{37}$ That

36. For the important prior scholarship, see the works cited supra note 7.

37. Locke had written:

Though I have said ... That all Men by Nature are equal, I cannot be supposed to understand all sorts of Equality ... the Equality I there spoke of, as proper to the Business in hand, being that equal Right that every Man hath, to his Natural Freedom, without being subjected to the Will or Authority of any other Man.

JOHN LOCKE, TWO TREATISES OF GOVERNMENT 322 (Peter Laslett ed., 2d ed. 1967) (bk. II, ch. VI, § 54) [hereinafter LOCKE, TREATISES]. Americans frequently declared that individuals in the state of nature were equally free. According to the 1776 Virginia Declaration of Rights, for example, "all Men are by Nature equally free and independent." Va. Decl. of Rights \& I (1776). Or, in the words of the 1776 Pennsylvania Constitution, "all men are born equally free and independerit" PA. CONST. of 1776, DECL. OF RIGHTS, art. I. As the Anti-Federalist "Brutus," wrote, "[i]f we may collect the sentiments of the people of America, from their own most solemn declarations, they hold this truth as self evident, that all men are by nature free." "Brutus," N.Y. J., Nov. 1, 1787, reprinted in 2 THE COMPLETE ANTI-FEDERALIST 372 (Herbert J. Storing ed., 1981). So common was the assumption of equal freedom in the state of nature that "[n]o man denies but that originally all were equally free." SAMUEL. WEBSTER, A SERMON 22 (Mass. election sermon 1777) (Evans 15,703). At the 1787 Constitutional Convention, Luther Martin addressed the issue: "In order to prove that individuals in a State of nature are equally free \& independent he read passages from Locke, Vattel, Lord Summers-Priestly." James Madison, Notes (June 27, 1787), in 1 THE RECORDS OF THE FEDERAL CONVENTION OF 1787 at 437 (Max Farrand ed., rev. ed. 1937) [hereinafter FEDERAL CONVENTION RECORDS]. For a few of the many other possible examples, see the following. "All men, indeed, are by nature equal: and all have, most certainly, an equal right to freedom and liberty by the great law of nature. No man or number of men, has or can have a right to infringe the natural rights, liberties or privileges of others: or to dominion or government over any one, but by his free consent personally, or by his legal representative, God having created the human species upon a level." PETER POWERS, JESUS CHRIST THE TRUE KING AND HEAD OF GOVERNMENT 10 (Vt. election sermon 1778) (Evans 16,019). Quoting Locke, the Rev. Stillman said that "creatures of the same species and rank, promiscuously born to all the same advantages of nature, and the use of the same faculties, should also be equal one amongst another without subordination or subjection' . . . . [W] ought firmly to maintain the natural equality of all men." SAMUEL STILLAN, A SERMON 8 (Mass. election sermon 1779) (Evans 16,537). "All men, by nature, are free, equal, and independent ...." JONAS CLARK, A SERMON 9 (Mass. election sermon 1781) (Evans 17,114). "EQUALTTY and INDEPENDENCE are the just claim, the indefeasible birth-right of men:-In a state of nature, as individuals; in society, as states or nations." Id. at 11 . The Rev. Gershom C. Lyman said of the "ruler" that he should consider mankind "as the same order and species of beings with himself-equal by nature-having equal rights—of equal importance in the sight of God-as rational creatures, who are to be bound by no laws which are not founded in reason ...." GERSHOM C. LYMAN, A SERMON 6 (Vt. election sermon 1782, published 1784) (Evans 18,566). "If all men are by nature equal, and no one has power and authority over another, then lawful authority to govern must be derived from mutual consent." ASA BURTON, A SERMON 10 (Vt. election sermon 1785, published 1786) (Evans 19,536). "[A]ll men are by nature equally free." ISRAEL. EVANS, A SERMON 9-10 (N.H. election sermon 1791) (Evans 23,358); see also HENRY CUMNGS, A SERMON 
is, they understood natural liberty to be the freedom an individual could enjoy as a human in the absence of government. A natural right was simply a portion of this undifferentiated natural liberty. Accordingly, Americans often broadly categorized natural rights as consisting of life, liberty and property, or life, liberty and the pursuit of happiness. Americans could, however, be more specific. They repeatedly said that the free exercise of religion or freedom of conscience was a natural right ${ }^{38}$ They also talked of the freedom of speech and press as a natural right. Patrick Henry, for example, assumed that "the freedom of the press" was among "the rights of human nature." ${ }^{39}$ Similarly, the right of self-

6 (Mass. election sermon 1783) (Evans 17,899).

38. "Brutus" said: "But it is not necessary ... that individuals should relinquish all their natural rights. Some are of such a nature that they cannot be surrendered. Of this kind are the rights of conscience, the right of enjoying and defending life, etc." "Brutus," supra note 37, at 373. Madison wrote "that in matters of Religion no man's right is abridged by the institution of Civil Society and that Religion is wholly exempt from its cognizance." James Madison, A Memorial and Remonstrance (ca. June 20, 1785), in 8 THE PAPERS OF JAMES MADISON 298, 299 (Robert A. Rutland et al. eds., 1973) [hereinafter MADISON PAPERS]. The Rev. Samuel Stillman, a Massachusetts Baptist, wrote of the "Rights of Conscience" that "in a state of nature, and of civil society [they] are exactly the same. They can neither be parted with nor controled, by any.human authority whatever." STILMAN, supra note 37, at 11 (Mass. election sermon 1779) (Evans 16,537); see also the Connecticut dissenter, ISRAEL HOLLY, A WORD IN ZION'S BEHALF 17-18 (1765) (Evans 10,005). Presbyterian dissenters in Virginia petitioned:

Religion is altogether personal, and the right of exercising it unalienable; and it is not, cannot, and ought not to be, resigned to the will of the society at large; and much less to the legislature, which derives its authority wholly from the consent of the people, and is limited by the original intention of civil associations.

Memorial of the Presbyterians of Virginia to the General Assembly (Aug. 13, 1785), in AMERICAN STATE PAPERS BEARNG ON SUNDAY LEGISLATION 113-14 (William A. Blakely ed., 1911) [hereinafter AMERICAN STATE PAPERS]. This was not, however, exclusively the position of dissenters. See, e.g., AMOs ADAMS, RELIGIOUS LIBERTY, AN INVALUABLE BLESSING 30-32 (1768)(Evans 10,810); SIMEON HOWARD, A SERMON (1780), in THE PULPIT OF THE AMERICAN REVOLUTION 373 (photo. reprint 1970) (John W. Thomton ed, 1860); [ELISHA WILLIAMS?], THE ESSENTIAL RIGHTS AND LIBERTIES OF PROTESTANTS, reprinted in POLITCAL SERMONS, supra note 30 , at $51,61,86,117$.

As is suggested by the passages quoted here, the free exercise of religion was the one natural right that many Americans agreed could not normally be submitted to the restraints or regulations of civil government. For some qualifications, however, see infra note 107.

39. Patrick Henry said:

With respect to the freedom of the press, I need say nothing; for it is hoped that the gentlemen who shall compose Congress will take care to infringe as little as possible the rights of human nature. This will result from their integrity. They should, from prudence, abstain from violating the rights of their constituents. They are not, however, expressly restrained. But whether they will intermeddle with that palladium of our liberties or not, I leave you to determine.

3 DEBATES ON THE ADOPTION OF THE FEDERAL CONSTITUTION 449 (photo. reprint 1987) (Jonathan Elliot ed, 1836) (statement of Patrick Henry in Va. ratification convention) [hereinafter ELLIOT's DEBATES]. An anonymous author, perhaps Elisha Williams, wrote that part of the "natural liberty" Englishmen and, he presumed, other individuals did not part with when they entered into a "state of govemment" was "the right that every one has to speak his sentiments openly concerning such matters as affect the good of the whole." [ELISHA WILLIAMS?], THE ESSENTIAL RIGHTS AND LIBERTIES OF PROTESTANTS, reprinted in POLITICAL SERMONS, supra note 30, at 51, 60; for the natural right to read, see $i d$. at 61 . In July 1787 , in a proposed committee report on what became the Bill of Rights, Roger Sherman wrote that " $[t]$ he people have certain natural rights which are retained by them when they enter society, Such are the rights ... of Speaking, writing and publishing their Sentiments with decency and freedom." Roger Sherman, Proposed Committee Report (July 21-28, 1789), in CREATTNG THE BIL OF RIGHTS 266, 267 (Helen E. Veit et al. eds., 1991). A Federalist wrote that liberty of the press "is what the people, for whom the late Convention were acting, look upon as a privilege, with which every inhabitant is born; - a right which Nature, and Nature's God, has given, ..." "UNCUS," MD. J., Nov. 9, 1787, reprinted in 14 THE DOCUMENTARY HISTORY OF THE RATIFICATION OF THE CONSTTTUTION 76, 78 (John P. Kaminski et al. eds., 1983) [hereinafter DOCUMENTARY HISTORY 
defense, the right to bear arms, and the right to assemble were said to be natural rights, and some of these, as we know, were enumerated in bills of rights. ${ }^{40}$ Significantly, the right to one's reputation was also frequently identified as a natural right. ${ }^{41}$

In contrast, Americans said that certain other rights, such as habeas corpus and jury rights, existed only under the laws of civil government. ${ }^{42}$ These were

OF THE CONSTITUTION]. In the notes for his speech introducing the amendments that eventually became the Bill of Rights, James Madison wrote: "Contents of Bill of Rhts. . . 3. natural rights retained as speach ... . 4. positive rights resultg. as trial by jury." James Madison's Notes for Amendments Speech (1789), in 2 THE BILL OF RIGHTS: A DOCUMENTARY HISTORY 1042 (Bernard Schwartz ed., 1971) [hereinafter DOCUMENTARY HISTORY OF THE BILL OF RIGHTS]; see also "HORTENSIUS" [GEORGE HAY], AN ESSAY ON THE LIBERTY OF THE PRESS 37 (1799) (Evans 35,605); GERSHOM RAYMOND, IN WHAT ONLY TRUE RELJGION CONSIST's (1788) (Evans 45,348) (quotation from preface). For an English discussion of the natural rights of speech and press, see JAMES TYRRELL, A BRIEF DISQUISITION OF THE LAW OF NATURE, ACCORDING TO THE PRINCIPLES AND METHOD LAID DOWN IN THE REVEREND DR. CUMBERLAND'S . . TREATISE . . . , at 92-95 (1692). Professor Leonard Levy notes that, in the eighteenth century, both Englishmen and Americans frequently said that freedom of speech was a natural right. See LEVY, supra note 14, at 103, 117, 137, 142, 224.

Assuming that the state of nature was merely an imagined historical condition of the distant past, Levy says that "the liberty of the press was probably distinguishable as a right that did not exist in the state of nature." LEVY, supra note 14, at 224. Of course, many eighteenth-century Americans understood the freedom of the press to be a freedom to publish rather than merely a freedom to print. More generally, they often understood the state of nature to be a conceptual rather than an historical situation. Thus, it could be quite contemporary. For example, it could exist among nations.

40. For the right to bear arms and self-defense generally, see STEVEN P. HALBROOK, THAT EVERY MAN BE ARMED: THE EVOLUTION OF A CONSTITUTIONAL RIGHT 87, 90, 92 (1984); see also I WILIAM BLACKSTONE, COMMENTARIES * 139. For the right of assembly, see, e.g., Roger Sherman, Proposed Committee Report, (July 21-28, 1789), in CREATING THE BILL OF RIGHTS, supra note 39, at 267.

41. In his lectures at Princeton, John Witherspoon included in a list of natural rights "[a] right to character, that is to say, innocence (not fame)." WITHERSPOON, supra note 25, at 123 (Of Politics). One appeal to the right of reputation arose in 1788, when Oswald, the notorious Anti-Federalist Philadelphia newspaper publisher, impugned the character of Browne, a local headmaster of a school for girls. In the ensuing case, Respublica v. Oswald, 1 U.S. (1 Dall.) 319 ( $\mathrm{Pa} .1788$ ), the Pennsylvania Supreme Court held that Oswald's publication amounted to contempt. When Oswald petitioned the state legislature to impeach the judges, Representative William Lewis defended the court's action, observing, among other points, the natural law origins of the right to reputation:

[H]e then commented upon the origin, nature, and purposes of a state of society, which, he said, was principally formed to protect the rights of individuals; and, of those rights, he pathetically described the right of enjoying a good name, to be the most important and the most precious. He observed, that the injuries which could be done to any other property, might be repaired; but reputation was not only the most valuable, but, likewise, the most delicate of human possessions. It was the most difficult to acquire; when acquired, it was the most difficult to preserve; and when lost, it was never to be regained. If, therefore, it was not as much protected, as any other right, the aged matron, and the youthful virgin (since purity of character is the palladium of female happiness) while they are fettered by the habits and expectations of society, are exposed and abandoned by its laws and institutions. But this evil is effectually removed, when we consider the bill of rights as precluding any attempt to restrain the press, and not as authorizing insidious falsehoods and anonymous abuse. The right of publication, like every other right, has its natural and necessary boundary; for, though the law allows a man the free use of his arm, or the possession of a weapon, yet it does not authorize him to plunge a dagger in the breast of an inoffensive neighbour.

Oswald, 1 U.S. (1 Dall.) at 329-30 n.*; see also JAMES WILSON, Lectures on Law, in 2 THE WORKS OF JAMES WILSON 593-96, 649-52 (Robert G. McCloskey ed., 1967) [hereinafter WORKS OF JAMES WILSON]. For an influential Scottish text on the subject, see 2 FRANCIS HUTCHESON, A SHORT ÍNTRODUCTION TO MORAL PHLOSOPHY 118 (5th ed. 1788) (bk. II, ch. iv, § 3) (Evans 21,164).

42. During the debates in the House of Representatives about the Bill of Rights, Madison generalized about American bills of rights: 


\section{rights that did not exist in the state of nature but were guaranteed in constitutions because they were essential for restraining government. ${ }^{43}$ These were civil rights}

In some instances they assert those rights which are exercised by the people in forming and establishing a plan of government. In other instances, they specify those rights which are retained when particular powers are given up to be exercised by the legislature. In other instances, they specify positive rights, which may seem to result from the nature of the compact. Trial by jury cannot be considered as a natural right, but a right resulting from a social compact which regulates the action of the community, but is as essential to secure the liberty of the people as any one of the pre-existent rights of nature.

James Madison, Speech in House of Representatives, (June 8, 1789), in CREATING THE BLL OF RIGHTS, supra note 39, at 81; see also James Madison's Notes for Amendments Speech (1789), in 2 DOCUMENTARY HISTORY OF THE BLL OF RIGHTS, supra note 39, at 1042; Joseph Hawley, Criticism of the Constitution of Massachusetts, in 3 SMITH COLLEGE STUDIES IN HISTORY 5, 40 (Mary C. Clune ed., 1917).

The "Federal Farmer" listed what he considered "unalienable or fundamental rights in the United States" and included in his list habeas corpus, the jury, and various other rights not normally considered natural rights. "FEDERAL FARMER" (Dec. 25, 1787), reprinted in 2 THE COMPLETE ANTI-FEDERALIST, supra note 37, at 262. Although inalienable rights were, more often than not, inalienable natural rights, the Federal Farmer appears to have been using the word "unalienable" to refer to both natural and acquired rights that, he thought, should be stipulated in the Constitution so as not to be left to the discretion of government. These were what the Federal Farmer and others normally said were "essential rights." That the Federal Farmer did not consider habeas corpus and jury rights to be inalienable natural rights is evident from the following passage from his discussion of rights:

[S] ome are natural and unalienable, of which even the people cannot deprive individuals: Some are constitutional or fundamental; these cannot be altered or abolished by the ordinary laws; but the people, by express acts, may alter or abolish them--These, such as the trial by jury, the benefits of the writ of habeas corpus ... individuals claim under the solemn compacts of the penple, as constitutions, or at least under laws so strengthened by long usuage [sic] as not to be repealable by the ordinary legislature-and some are common or mere legal rights, that is, such as individuals claim under laws which the ordinary legislature may alter or abolish at pleasure.

2 Id. at 261 ; see also 2 id. at 328.

Richard Henry Lee-who may have been the Federal Farmer-wrote:

[T] residuum of human rights, which is not intended to be given up to society, and which indeed is not necessary to be given for any good social purpose. The rights of conscience, the freedom of the press, and the trial by jury are at mercy.

RICHARD H. LEE, LETTER TO THE GOVERNOR, reprinted in 5 THE COMPLETE ANTI-FEDERALIST, supra note 37, at 114. Conceivably, this passage could be understood to indicate that Lee considered the jury a natural right. Yet, in the context of a federal constitution, it may be doubted whether Lee considered the "residuum" to consist merely of natural rights. For recent scholarship suggesting that Lee was not the Federal Farmer, see 14 DOCUMENTARY HISTORY OF THE CONSTITUTION, supra note 39, at 16.

On the other hand, during ratification of the 1780 Massachusetts Constitution, the town of Roxbury complained of the proposed habeas corpus clause:

We object to it in its present Form because we think the legislature ought not to be the Judges of the expedience of suspending a Natural Right which every Subject enjoys of having an enquiry made into the cause of his imprisonment if it is necessary at any time, we think the Constitution ought to point out when this Necessity exists-as in time of War, Invasion, and Rebellion, and then for a Term not exceeding Six Months, at any one time.

Sentiments of the Town of Roxbury on the Constitution of Civil Government proposed by Convention, in THE POPULAR SOURCES OF POLITICAL AUTHORITY 793 (Oscar \& Mary Handlin eds., 1966).

Note that eighteenth-century Americans typically had little reason to mention that a right was a right not existing in the state of nature. In contrast, Americans more frequently had polemical reasons to point out the natural basis of such rights as were natural rights.

43. Americans used varying labels for acquired rights. For example, an anonymous Anti-Federalist wrote: To define what portion of his natural liberty, the subject shall at all times be entitled to retain, is one great end of a bill of rights. To these may be added in a bill of rights some particular engagements of protection, on the part of government[;] without such a bill of rights, firmly securing the privileges of the subject, the government is always in danger of degenerating into tyranny; for" it is certainly true, that "in establishing the powers of government, the rulers are 
not merely in the sense that they were protected by constitutions or other civil laws, but also in the sense that they were acquired rights. They were rights that could exist only under civil government. ${ }^{44}$

Thus, Americans distinguished between civil guarantees of natural rights and civil guarantees of rights that did not exist in the state of nature ${ }^{45}$-and they considered the free speech and press clause of the Bill of Rights a civil guarantee of a natural right. ${ }^{46}$

\section{NATURAL LAW AND NATURAL RIGHTS}

Americans - that is, of course, Americans who discussed, or at least silently considered, natural liberty and natural law-understood natural liberty in a way that reflected their ideas of natural law. They assumed that natural law consisted of reasoning about how to exercise and preserve natural liberty and that natural liberty was subject to the implications of natural law. In more concrete terms,

invested with every right and authority, which is not in explicit terms reserved" . . . Hence it is that we find the patriots, in all ages of the world, so very solicitous to obtain explicit engagements from their rulers, stipulating, expressly, for the preservation of particular rights and privileges.

"OLD WHIG," reprinted in 3 THE COMPLETE ANTI-FEDERALIST, supra note 37, at 33. Arguing that no harm arose from the absence of a bill of rights, Theophilus Parsons said:

Is there a single natural right we enjoy, uncontrolled by our own legislature, that Congress can infringe? Not one. Is there a single political right secured to us by our constitution, against the attempts of our own legislature, which we are deprived of by this Constitution? Not one, that I recollect.

2 ELLIOT'S DEBATES, supra note 39, at 93 (statement of Theophilus Parsons in Mass. Ratification Convention).

44. To avoid the ambiguity, some Americans called these "adventitious rights." A different use of "adventitious rights" is discussed by MORTON G. WHITE, THE PHILOSOPHY OF THE AMERICAN REVOLUTION 213-21 (1978). For the convenience of lumping together all of the natural and civil rights deserving of constitutional protection, Anti-Federalists and other Americans often simply talked about guarantees for "essential rights." They also, however, revealed a willingness to distinguish between natural rights and those not existing in the state of nature.

45. Americans frequently adapted the general analysis presented here to make it accommodate their particular claims. For example, religious dissenters who sought equal civil rights with respect to religious differences sometimes obtained constitutional guarantees of only the natural right of free exercise of religion. Therefore, they occasionally insisted that these constitutional guarantees of the natural right provided them with what normally were considered rights existing only in civil society. Strikingly, however, eighteenthcentury Americans who made these ambitious claims did not attempt to alter the general state-of-nature or natural rights analysis. Philip A. Hamburger, Equality and Diversity: The Eighteenth Century Debate About Equal Protection and Equal Civil Rights, 1992 SUP. CT. REv. (forthcoming).

46. Indeed, Americans did not typically claim a right to government benefits for their speech or press. For example, in 1787-88, some Anti-Federalists said that the Post Office was refusing to deliver Anti-Federalist newspapers - in particular, that it was no longer delivering these papers without charge. A number of AntiFederalists said this impeded the exercise of the freedom of the press. 16 DOCUMENTARY HISTORY OF THE CONSTITUTION, supra note 39, at 540-96 app. II. There is, however, no clear evidence that many persons - even many Anti-Federalists-considered this a violation of the natural right of freedom of the press. They tended to say that the postal privilege of printers of newspapers was an ancient custom or usage or that this was an important means of communication for the freedom of the press, particularly in a republic. As George Washington wrote, "[i]f the priviledge was not from convention an original right, it had from prescription strong pretensions for continuance; especially at so interesting a period." Letter from George Washington to John Jay (July 18, 1788), in 16 DCCUMENTARY HISTORY OF THE CONSTTTUTION, supra note 39 , at 596. 
natural law was a limitation on natural liberty in the sense that humans were capable of reasoning about their liberty and interests. ${ }^{47}$

Americans tended to take for granted that natural law had a foundation in the physical world and yet had moral implications. Natural law, according to Americans, was a type of reasoning about how individuals should use their freedom. Typically, these Americans explained the physical basis of natural law reasoning by saying that it was based on assumptions about humans and human freedom in the state of nature..$^{48}$ For purposes of the political analysis examined

47. Of course, this approach had European origins. For example, Locke wrote: "Law, in its true Notion, is not so much the Limitation as the direction of a free and intelligent Agent to his proper interest." LOCKE, TREATISES, supra note 37, at 323 (bk. II, ch. vi, § 57). According to the Swiss writer, Burlamaqui:

[T] he restrictions, which the law of nature makes to the liberty of man, far from diminishing or subverting it, on the contrary constitutes [sic] its perfection and security. The end of natural laws is not so much to restrain the liberty of man, as to make him act agreeably to his real interests; and moreover, as these very laws are a check to human liberty, in whatever may be of pernicious consequence to others, it secures, by these means, to all mankind the highest and the most advantageous degree of liberty they can reasonably desire.

2 JeAN-JACQUES BURLAMAQU, THE PRINCIPLES OF THE NATURAL AND POLITIC LAW 17 (Nugent trans., 1807) (1763) (pt. I, ch. iii, § 18).

48. On the law of nature, see Walter Berns, The New Pursuit of Happiness, 86 PUB. INTEREST 65,67 (1987); Berns, supra note 7. Morton White discusses the dual role of natural law but places great emphasis on the work of Hooker, which represented a pre-Hobbesian approach to the issue. See WHITE, supra note 44 , at $150-57$.

For human beings, the law of nature was the law of human nature. Thus, Abraham Williams said: "The Law of Nature (or those Rules of Behaviour, which the Nature God has given Men, the Relations they bear to one another, and the Circumstances they are placed in, render fit and necessary to the Welfare of Mankind) is the Law and Will of the God of Nature, which all Men are obliged to obey." ABRAHAM WILIAMS, A SERMON 9 (Mass. election sermon 1762) (Evans 9310). The sometime Chief Justice of Vermont. Nathaniel Chipman, described his essay on political theory as "a sketch ... of the constitutional principles of government; as founded in the principles of natural law, in the moral and social nature of man." NATHANIEL CHIPMAN, SKETCHES OF THE PRINCIPLES OF GOVERNMENT 115 (1793) [hereinafter CHIPMAN, SKETCHES]. He also wrote: "It is at length perceived, that the operations of nature are subjected to certain laws, established by Deity, in the constitution of things." Id. at 283.

Incidentally, contrary to some modern historical assumptions, natural liberty was frequently said to be established by natural law. For example, Richard Bland talked about "the Law of Nature, and those Rights of Mankind which flow from it." RICHARD BLAND, AN INQUIRY DNTO THE RIGHTS OF THE BRITISH COLONIES (1766), reprinted in 1 AMERICAN POLITICAL WRIIING, supra note 29, at 75. According to the first Continental Congress, "the inhabitants of the English colonies in North-America, by the immutable laws of nature, the principles of the English constitution, and the several charters or compacts, have the following RIGHTS. ... That they are entitled to life, liberty, and property ..." First Continental Congress, Declaration and Resolves of Oct. 14, 1774, in JOURNAL OF THE PROCEEDINGS OF THE CONGRESS HELD AT PHLADELPHIA, SEPTEMBER 5, 1774, at 60 (photo. reprint 1974) (1774). The Georgia Constitution asserted that the conduct of the British, "being repugnant to the common rights of mankind, hath obliged the Americans, as freemen, to oppose such oppressive measures, and to assert the rights and privileges they are entitled to by the laws of nature and reason; ..." GA. CONST. of 1777, pmbl. John Witherspoon told his students at Princeton that "men are originally and by nature equal, and consequently free." WTHERSPOON, supra note 25, at 124 (Lecture X). The Rev. Peter Powers preached that "all have, most certainly, an equal right to freedom and liberty by the great law of nature." The basis of equal liberty was that "God . . . created the human species upon a level." PowERS, supra note 37, at 10 (Vt. election sermon 1778) (Evans 16,019). An Anti-Federalist said that "every natural right is . . . [a] power or claim established by the law of nature." "The Impartial Examiner," VA. INDEP. CHRON., Feb. 20, 1788, reprinted in 5 THE COMPLETE ANTI-FEDERALIST, supra note 37, at 177. Another, "Brutus," wrote that "[i]f we may collect the sentiments of the people of America, from their own most solemn declarations, they hold this truth as self evident, that all men are by nature free." "BRUTUS" reprinted in 2 THE COMPLETE ANTI-FEDERALIST, supra note 37, at 372. Mercy Warten approximately quoted Blackstone that "the principal aim of society is to protect individuals in the absolute rights which were vested in them by the immediate [sic immutable] laws of nature." "A COLUMBLAN 
here, they tended to focus on two such assumptions: that individuals in the state of nature were equally free ${ }^{49}$ and that these individuals were to preserve themselves and their liberty. ${ }^{50}$

These two assumptions, although related to the physical world, had moral implications. Being equally free, individuals did not have a right to infringe the equal rights of others, and, correctly understood, even self-preservation typically required individuals to cooperate-to avoid doing unto others what they would not have others do unto them. ${ }^{51}$ In this way, the assumptions about humans and, particularly, human liberty in the state of nature-that individuals in the state of nature were equally free and that such individuals should seek to preserve their liberty-were considered to be foundations upon which humans could reason about cooperative behavior for the preservation of that liberty. These assumptions could, in fact, be used to justify rules that bore a striking resemblance to some of the social duties of traditional morality. In keeping with this reasoning, one minister entitled his sermon to the 1779 Vermont constitutional convention, A Well Tempered Self-Love [is] a Rule of Conduct Towards Others. ${ }^{52}$ Thus, Americans derived social obligations from enlightened self-interest-morality from something deceptively similar to materialism - and therefore could talk about natural law both as a law of human nature and as the foundation of moral rules..$^{53}$

PATRIOT" [MERCY WARREN], OBSERVATIONS ON THE CONSTITUTION, reprinted in 16 DOCUMENTARY HISTORY OF THE CONSTITUTION, supra note 39, at 278, following 1 WILLIAM BLACKSTONE, COMMENTARIES *124; see also NATHANIEL CHIPMAN, PRINCIPLES OF GOVERNMENT 55 (1833) [hereinafter CHIPMAN, PRINCIPLES]; CHIPMAN, SKETCHES, supra, at 37; "Republicus," KY. GAZ., Feb. 16, 1788, reprinted in 8 DOCUMENTARY HISTORY OF THE CONSTITUTION, supra note 39, at 376. Similarly, Americans could speak of the "rights of human nature." Report on the Address to the States by Congress (April 26, 1783), in 6 MADISON PAPERS, supra note 38 , at $493-94$.

49. See supra note 37 ; see also supra note 48 .

50. Whereas some Americans followed Hobbes in saying that individuals in the state of nature were in a state of war, many others disagreed, and the issue was debated in academic settings. For example, at the first commencement of Washington College, Maryland, in 1783, four of the five graduates participated in an "English Forensic Debate" on the question, "Whether the state of nature be a state of war?" 2 LIFE AND CORRESPONDENCE OF THE REV. WILLIAM SMITH, D.D. 88 (photo. reprint 1972) (Horace W. Smith ed., 1880). Nonetheless, Americans tended to agree that individuals and their liberty in the state of nature were to some degree insecure, and that individuals, on this account, had to preserve themselves and their liberty by forming government. See infra notes $69-72 \& 74$ and accompanying text.

51. The exception was if others failed to conform to natural law. If, in the words of Locke, a person transgressed the law of nature, "the Offender declares himself to live by another Rule, than that of reason and common Equity." LOCKE, TREATISES, supra note 37, at 290 (bk. II, ch. ii, § 8).

52. AARON HUTCHINSON, A WELL TEMPERED SELF-LOVE A RULE OF CONDUCT TOWARDS OTHERS (1779) (Evans 15,855).

53. Witherspoon optimistically told his students: "The different foundations of virtue are many of them, not opposite or repugnant to each other, but parts of one great plan-as benevolence and self-love, \&c. They all conspire to found real virtue: the authority of God-the dictates of conscience-public happiness and private interest all coincide." WITHERSPOON, supra note 25 , at 187 (Recapitulation). Self-preservation, or "self-love," was not traditionally a mere desire or instinct. It was a divinely ordained goal for humans that approximately coincided with human instinct and convenience. See JAMES TULLY, A DISCOURSE ON PROPERTY: JOHN LOCKE AND HIS ADVERSARIES $46-47$ (1980). For example, the Rev. Peter Powers insisted that "[t]he original law our Maker gave us, commonly called the law of nature, was not a blind law of instinct, but the eternal rule of righteousness, the moral law, agreeably to the nature of the divine perfections." POWERS, supra note 37, at 9 (Vt. election sermon 1778) (Evans 16,019). Nathaniel Chipman also rejected 
Of course, Americans varied considerably in their accounts of natural law. ${ }^{54}$ Although many described the moral implications of natural law as consisting of prudential rules of noninjurious behavior derivable from principles of equal freedom and self-preservation, they frequently also derived duties to government, on the ground that government was necessary for the preservation of the liberty of individuals. Many, moreover, associated equal liberty and self-preservation with the assumption that man was a social being with a duty to society. Man's social character could be treated as an additional ground for arguing that individuals typically should not violate the equal rights of others, or as the foundation of a more complete set of moral duties. ${ }^{55}$ Another variation involved

the notion that natural law consisted of "instinct" or "blind impulses," although he appears to have done so in order to emphasize that humans could, unfortunately, deviate from natural law. See CHIPMAN, SKETCHES, supra note 48 , at 50, 51 n.*, 83.

Of course, it was not altogether clear that the enlightened self-interest associated with natural law always lay in an accommodation of the equal rights of others. For this reason, and because some men would not be so perspicuous as to recognize even that which was clearly in their self-interest. Pufendorf and many eighteenth-century Americans considered religion a necessary supplement to the law of self-preservation. The rules of conduct that a perceptive man might be able to derive from the goal of self-preservation in this world, another man less observant or simply less inclined to wishful thinking might, nonetheless, accept on account of rewards and punishments in the next world. See, e.g., SAMUEL PUFENDORF, DE JURE NATURAE ET GENTIUM LIBRI OCTO 217-24 (C.H. Oldfather \& W.A. Oldfather trans., 1934) (1688 ed.) (bk. II, ch. iii, \$§ 20-21). For a discussion of seventeenth-century English analysis of this issue, see JOHN LOCKE, QUESTIONS CONCERNING THE LAW OF NATURE 24 (Robert Horwitz et al. eds. and trans., 1990) [hereinafter LOCKE, QUESTIONS].

54. Among the differences that will not be pursued here was the distinction between the deductive and the inductive approach to natural law. See infra note 58 . For other differences concerning epistemological problems, the character of natural law, and the role of religious belief, see, e.g., LOCKE, QUESTIONS, supra note 53, at 1-62; Murray Forsyth, The Place of Richard Cumberland in the History of Natural Law Doctrine, 20 J. HIST. PHI. 23, 38-39 (1982).

These eighteenth-century disputes about the philosophical basis of natural law generated much leamed and important commentary, but are not very pertinent to this account. As the English lecturer, Rutherforth, observed, these disagreements did not greatly affect what eighteenth-century men understood to be the theory's moral and political conclusions:

As it is the principal design of the following treatise to trace out the rules, which mankind are obliged to observe from their nature and constitution; there does not seem to be any great necessity for entering into the question concerning the cause of our obligation to observe these rules; a question upon which moralists are so much divided in their opinions. However they may differ about the cause of obligation, they are agreed about the law, to which we are obliged; whilst they dispute about the reason of duty, they concur in establishing the same rules of duty. The moralists of one sect derive our obligation to observe the law of nature from instinctive affections, or an innate moral sense. Those of another sect maintain, that all our obligations of this sort arise from certain abstract relations or fitnesses of things. A third sect are of the opinion, that we cannot be steadily and constantly obliged to the observance of that law, but from the assurance of being made happy, for observing it, by the will and appointment of God. And a fourth sect think it necessary to join all these principles together, in order to render the obligation perfect. ... But as the rules of duty are the proper subject of our present inquiry, and all moralists are agreed about these rules, however they may differ about the cause, which obliges us to the observance of them; we might pass over this question entirely, without being liable to be charged with neglecting what necessarily belongs to our subject: or if we say any thing about it, those moralists, who are not of the same opinion with us, must own, that the proper subject of the following treatise is not affected by it.

RUTHERFORTH, supra note 26 , at 5 (bk. I, ch. $1, \S 6$ ).

55. An Anti-Federalist wrote that "an universal, and unerring observation of, and obedience to this law [of nature], is what we call rectitude, or moral virtue." "Republicus", KY. GAZ., Feb. 16, 1788, reprinted in 5 THE COMPLETE ANTI-FEDERALIST, supra note 37, at 161. According to an election sermon: 
not only duties to other individuals but also duties to oneself and the Deity. Although some writers on government and civil law acknowledged these additional kinds of natural law duties, large numbers of such authors, not surprisingly, paid them relatively little attention. Thus, Americans who discussed natural law had substantial differences. Nonetheless, they tended to agree that natural law consisted of reasoning about humans in the state of nature and tended to emphasize that they were reasoning from the equal freedom of humans and the need of humans to preserve themselves. ${ }^{56}$ On this more or less common ground, it was utterly conventional to describe an immoral action as something that would "disgrace human nature" the other sciences, had its foundation in the physical world. ${ }^{58}$

[t]o do to our neighbor as we would that he should do to us is one of the plainest dictates of reason, and a law of universal equity and obligation. It comprehends the whole of social duty, and extends to kindness, humanity and mercy, as well as to truth and justice.

ELIZUR GOODRICH, THE PRINCIPLES OF CIVIL UNION AND HAPPINESS 13-14 (Conn. election sermon 1787) (Evans 20,393); see also id. at 10.

56. Of course, reason, even if it was of divine institution, could appeal to an atheist as well as to a religious person:

These moral principles and connections are moral laws, not only, as they point out a fixed order of events respecting moral ends, in which the meer politician, who has no fear of GOD before his eyes, may consider them; but to the enlightened and religious mind, they are moral laws, in a higher sense-laws of our creator, for the conduct of our life and manners.

GOODRICH, supra note 55, at 12 (Conn. election sermon 1787) (Evans 20,393).

57. Letter from Samuel H. Parsons to William Cushing (Jan. 11, 1788), in 3 DOCUMENTARY HISTORY OF THE CONSTITUTION, supra note 39, at 573; see also "Philanthrop," AM. MERCURY, Nov. 19, 1787, reprinted in 3 DOCUMENTARY HISTORY OF THE CONSTITUTION, supra note 39, at 469. Similarly, Jefferson could speak of "[t]he moral law of our nature." Thomas Jefferson, Opinion on the question whether the United States have a right to renounce the treaties with France (Apr. 28, 1793), in THE LIFE AND SELECTED WRITINGS OF THOMAS JEFFERSON 318 (Adrienne Koch \& William Peden eds, 1944) [hereinafter JEFFERSON, WRITNGS].

58. Note that this claim could be made, in different ways, both for the deductive approach and, perhaps, more persuasively, for the inductive approach. Only by adopting an analysis of natural law that was based on an accurate understanding of human beings could speculative writers make morality and politics the subjects of useful, rather than utopian theories. For instance:

These laws may be considered as principles, in respect of their fixedness and operation; and as maxims, since by the knowledge of them, we discover those rules of conduct, which direct mankind to the highest perfection, and supreme happiness of their nature. They are as fixed and unchangeable as the laws which operate in the natural world.

Human art in order to produce certain effects, must conform to the principles and laws, which the Almighty Creator has established in the natural world. ... For he, who at[t]empts these things, on other principles, than those of nature, attempts to make a new world; and his aim will prove absurd and his labour lost.

GOODRICH, supra note 55, at 8-9 (Conn. election sermon 1787) (Evans 20,393). Phillips Payson preached that "common and well known truths and real facts, ought to determine us in human matters. We should take mankind as they are, and not as they ought to be, or would be, if they were perfect in wisdom and virtue." PHILlIPS PAYSON, A SERMON 25 (Mass. election sermon 1778) (Evans 15,956); see also CHIPMAN, SKETCHES, supra note 48, at 283. For British sources, see, e.g., DANIEL BOORSTIN, THE MYSTERIOUS SCIENCE OF LAW, ch. 1 (1967); WILLIAM WARBURTON, The Alliance Between Church and State, in 7 WORKS OF WILLIAM WARBURTON 36 (1811); Michael Hoeflich, Law and Geometry: Legal Science from Leibniz to Langdell, 30 AM. J. LEGAL HIST. 95, 108-19 (1986); Moral Philosophy, or Morals, in 3 ENCYCLOPEDIA BRITANNICA 270 (1771).

Many British writers sought to base their accounts on induction from empirical evidence rather than merely on deductive reasoning. In the words of the Encyclopedia Britannica, "Moral Philosophy has this in common with Natural Philosophy, that it appeals to nature or fact depends on observation; and builds its reasonings on plain uncontroverted experiments, or upon the fullest induction of particulars of which the subject will admit." Moral Philosophy, or Morals, in 3 ENCYCLOPEDIA BRITANNICA 270 (1771). 
If natural law consisted of reasoning about natural liberty, ${ }^{59}$ then natural liberty was subject to the implications of natural law. In the sense of a physical freedom, natural liberty was an individual's freedom or power to do as he or she pleased, without subordination or subjection to others, and, on the basis of this definition, an American discussing freedom of speech as a natural right could talk about an individual's "natural liberty or power."60 Yet, if all individuals in the state of nature were equally free from subordination to one another, then, as already suggested, none had a moral right to exercise his liberty in a way that infringed the equal freedom of another person. Drawing attention to this consequence of equality, a Vermont minister said, "all have, most certainly, an equal right to freedom and liberty by the great law of nature. No man or number of men, has or can have a right to infringe the natural rights, liberties or privileges of others .....61 Thus, the equality of liberty had implications for

Increasingly, Americans adopted the inductive approach. Witherspoon lectured that "perhaps a time may come when men, treating moral philosophy as Newton and his successors have done natural, may arrive at greater precision. It is always safer in our reasonings to trace facts upwards, than to reason downwards, upon metaphysical principles." WMTHERSPOON, supra note 25, at 186 (Recapitulation). In 1793, Chipman observed that "[w]ithin little more than a century, experimental reasonings have banished almost innumerable absurdities, and in many sciences, seem to have laid a foundation of knowledge, as fixed and as durable, as the course of nature." CHIPMAN, SKETCHES, supra note 48, at 283. The Americans who employed the inductive approach to natural law, however, apparently tended to do so in a way that did not disturb most of the conventional conclusions reached by the deductive approach.

59. Or if natural liberty was based on assumptions about natural law. See supra note 48 and accompanying text.

60. [ELISHA WILLIAMS?], THE ESSENTIAL RIGHTS AND LIBERTIES OF PROTESTANTS (1744), reprinted in POLITICAL SERMONS, supra note 30, at 60. Later in the century, a future Chief Justice of Connecticut, Zephaniah Swift, wrote: "Natural rights consist in our possessing and enjoying the power and privilege of doing whatever we think proper, without any other restraint than what results from the laws of nature." 1 ZEPHANIAH SWIFT, A SYSTEM OF THE LAWS OF THE STATE OF CONNECTICUT 176 (1795). According to Nathaniel Chipman, "Power, and liberty, are not of equal extent in signification. Power is, in a strict sense, that, by which we are enabled to exercise our liberty; not the liberty itself, when considered as a right. In a larger sense, it comprehends, both the right, and the power." CHIPMAN, SKETCHES, supra note 48, at 74.

For the distinction between moral liberty and physical freedom or power, see WHIE, supra note 44, at $186-95$.

61. POWERS, supra note 37, at 10 (Vt. election sermon 1778) (Evans 16,019). The eminent Baptist, Samuel Stillman, wrote:

And as they are equal, so they are likewise in a state of entire freedom. Whatever they possess

is their own; to be disposed of solely agreeable to their own will. None have a right to claim any part of their property, to disturb them in their possessions, or to demand subjection in any degree whatever, while they act consistent with the law of nature. He who attempts to do either, is an usurper, puts himself into a state of war, and may be opposed as a common highwayman.

STILLMAN, supra note 37, at 8-9 (Mass. election sermon 1779) (Evans 16,537). Rev. Hemmenway preached:

If I should attempt a definition or description of liberty in general, considered as a right or privilege claimable by mankind, I would say that it consists in a person's being allowed to hold, use and enjoy all his faculties, advantages, and rights, according to his own judgment and pleasure, in such ways as are consistent with the rights of others, and the duty we owe to our maker atid our fellow creatures. Liberty must never be used but within the bounds of right and duty. God allows us not to hold, use, or enjoy any thing to the injury of any one. A licence to do wrong and encroach on the rights of others, is no part of that liberty which God has granted us; nor is it any restraint of our true freedom for us to be restrained by laws from wicked, unreasonable and injurious actions.

MOSES HEMMENWAY, A SERMON 12 (Mass. election sermon 1784) (Evans 18,526). The "state of natural liberty" was a situation "wherein each individual" was "equally intitled to the enjoyment of all natural rights" and had "equally a just authority to exercise full powers of acting, with relation to other individuals, in any 
the extent of liberty; it suggested that there were some limits on an individual's freedom to do as he or she pleased and that these limits consisted of the equal rights of others. Put another way, the analysis of equal liberty implied a definition of injury, at least in the state of nature. For example, on the assumption that an individual's violation of the equal rights of others was an injury, Americans sometimes said that an individual ought not exercise his natural right of free speech in a way that injured another individual in his natural right to his reputation. ${ }^{62}$ What was implied by the principle of equal freedom was also supported by the principle of self-preservation. The principle of selfpreservation, as mentioned above, was understood to require, in most circumstances, that one not do unto others what one would not have them do unto oneself, ${ }^{63}$ and, in this way, the implication against injury was made compatible with enlightened self-interest. Thus, through the use of the reasoning that constituted natural law, individuals in the state of nature could calculate that they typically could best preserve their extensive physical freedom to do as they pleased by refraining from interfering with the equal liberty of others.

As should already be apparent, these conclusions about the implications of natural law for an individual's physical freedom or power in the state of nature

manner not injurious to their rights." "The Impartial Examiner," To the Free People of Virginia, VA. INDEP. CHRON., Feb. 20, 1788, reprinted in 5 THE COMPLETE ANTI-FEDERALIST, supra note 37, at 173, 176-77. "Republicus"-an Anti-Federalist-defined natural freedom as "a power of self government, a performance of all our actions agreeable to our own will; or in plainer terms, it is a doing as we please; under the direction of reason, the great, primary, and never-ceasing law of nature." "Republicus," KY. GAZ, Feb. 16, 1788, reprinted in 5 THE COMPLETE ANTI-FEDERALIST, supra note 37, at 160, 161. Justice James Iredell began a charge to a grand jury by observing that

liberty itself, in order to be truly enjoyed, must submit to reasonable and considerate restraints.

The unbounded liberty of the strongest man is tyranny to the weakest: The unlimited sway of a majority is oppression to the minority: Unlicenced indulgence to all the passions of men is an impious rejection of the controul of reason which Providence has given for their government and direction.

James Iredell, Charge to the Grand Jury of the Circuit Court for the District of Massachusetts (Oct. 12, 1792), in 2 DOCUMENTARY HISTORY OF THE SUPREME COURT OF THE UNITED STATES, 1789-1800, at 308, 310 (Maeva Marcus ed., 1988) [hereinafter DOCUMENTARY HisTORY OF THE SUPREME CoURT]. According to Zephaniah Swift, "[n]atural liberty consists in a man's having the power to do whatever he pleases, uncontrouled by any superior, and regarding only the moral law." I SwIFT, supra note 60, at 12; see also CHIPMAN, SKETCHES, supra note 48, at 75. In England, Blackstone wrote: "This natural liberty consists properly in a power of acting as one thinks fit, without any restraint or control, unless by the law of nature." 1 WILLIAM BLACKSTONE, COMMENTARIES *125. This sort of analysis remained in use for a long time; see, e.g., DAVID D. FIELD, SUGGESTIONS RESPECTING THE REVISION OF THE CONSTITUTION OF NEW YORK 5

(1867) ("Plan of a Constitution," \$\$ 1-2).

62. See supra note 41.

63. Clergymen sometimes turned to the Bible for a stronger account. For example, Rev. Hemmenway preached:

Natural Liberty does not consist in an exemption from the obligations of morality, and the duties of truth, righteousness and kindness to our fellow men; nor does it give any one a right to seize by force or fraud whatever he may have a mind for, how much soever it may be to the damage of others; as some have most absurdly taught. The obligation of the law of God, which we are all under, and which requires us to love our neighbor, and do as we would be done unto, does not take its force from human compacts.

HEMMENWAY, supra note 61, at 13 (Mass. election sermon 1784) (Evans 18,526). For a similar, later analysis, see BENJAMIN L. OLIVER, THE RIGHTS OF AN AMERICAN CITIZEN 42 (1832). 
often prompted and became intermingled with an analysis of natural liberty as a noninjurious and, in this sense, moral exercise of freedom. ${ }^{64}$ Put another way, whereas the physical freedom to do as one pleased was limited or restrained by natural law, another type of natural liberty was defined by natural law. The latter was, in Locke's words, the freedom to "to be under no other restraint but the Law of Nature. ${ }^{965}$ From a more overtly religious and moralizing perspective, the Reverend Peter Powers bluntly preached that "[l]iberty consists in a freedom to do that which is right." ${ }^{, 66}$ Of course, many Americans, particularly when discussing civil government and its laws, did not understand natural law to imply moral obligations as extensive as those probably contemplated by Powers. Nonetheless, Americans shared an understanding that natural liberty, as defined by natural law, was a moral liberty, in the sense that it was a liberty defined by such implications against injury as could be derived from the principles of human nature. ${ }^{67}$ For example, this analysis of a noninjurious, or, more broadly,

64. Sometimes it is difficult to determine which of these types of natural liberty an eighteenth-century author was discussing.

65. LOCKE, TREATISES, supra note 37, at 302 (bk. II, ch. iv, $\$$ 22). Locke also wrote: "But Freedom is not, as we are told, $A$ Liberty for every Man to do as he lists: . . . . But a Liberty to dispose, and order, as he lists, his Person, Actions, Possessions ... within the Allowance of those laws under which he is ...." Id. at 324 (bk. II, ch. vi, § 57). Also: "The Natural Liberty of Man is to be free from any Superior Power on Earth ... but to have only the Law of Nature for his Rule ..." Id. at 301 (bk. II, ch. iv, § 22). According to Samuel Parker-the seventeenth-century English bishop- "it is plain that Nature sets bounds to it self by the limitedness of its own Being, and that it is impossible there should ever be any state of Nature capable of an unlimited Right, for its liberty can never be greater than its Capacities . ..." SAMUEL PARKER, A DEMONSTRATION OF THE DIVINE AUTHORITY OF THE LAW OF NATURE, AND OF THE CHRISTIAN RELIGION 36 (1681); see also TYRRELL, DISQUISITION, supra note 39, at 36, 40, 41; 2 BURLAMAQUI, supra note 47, at $15-16$ (pt. I, ch. iii, $\S 15$ ).

66. POWERS, supra note 37, at 40 (Vt. election sermon 1778) (Evans 16,019). He continued: "The great law of nature, the moral law, is the rule of right action. This is the rule of moral and civil Liberty. Man's fall has taken away his freedom of right action ...."Id. For a somewhat controversial understanding of the New England interpretation of liberal thought, see ALAN HEDMERT, RELIGION AND THE AMERICAN MIND (1966).

67. In the 1740's, an American wrote:

This natural freedom is not a liberty for every one to do what he pleases without any regard to any law; for a rational creature cannot but be made under a law from its Maker: But it consists in freedom from any superiour power on earth, and not being under the will or legislative authority of man, and having only the law of nature (or in other words, of its Maker) for his rule.

[ELISHA WULIAMS?], THE ESSENTIAL RIGHTS AND LIBERTIES OF PROTESTANTS (1744), reprinted in POLITCAL SERMONS, supra note 30, at 56. Witherspoon alluded to "[t]he violation of the natural rights of mankind being a transgression of the law of nature." WITHERSPOON, supra note 25, at 151 (Lecture XIII). Jefferson wrote: "Questions of natural right are triable by their conformity with the moral sense and reason of man." Thomas Jefferson, Opinion on the question whether the United States have a right to renounce their treaties with France (Apr. 28, 1793), in JEFFERSON, WRITINGS, supra note 57, at 319. The 1792 Delaware Constitution declared that:

Through Divine Goodness all men have, by nature, the rights of worshipping and serving their Creator according to the dictates of their consciences, of enjoying and defending life and liberty, of acquiring and protecting reputation and property, and, in general, of attaining objects suitable to their condition, without injury by one to another. . . .

DEL. CONST. of 1792, pmbl.; see also JAMES WIISON, Lectures on Law, in 2 WORKS OF JAMES WRSON, supra note 41 , at 587 . 
a moral natural liberty justified vast numbers of Americans in distinguishing liberty from licens $e^{68}$ and treating those classifications as mutually exclusive.

Thus, natural law had implications for natural liberty. Natural law implied that individuals should restrain themselves in the exercise of their physical natural liberty, and it defined an individual's noninjurious or more broadly moral natural liberty.

\section{Civil LaW and Natural Rights}

In accordance with their understanding of natural law, Americans assumed that, under civil government, individuals retained only a portion of their natural liberty. They assumed that individuals retained only such natural rights as were reserved by a constitution or, much less securely, were left unimpeded by their other civil laws.

The American analysis of how individuals, acting in accordance with natural law, preserved their liberty by forming government is well known. As seen above, Americans assumed that individuals in the state of nature could reason that, if they were equally free, they had no right to interfere with the equal freedom of others-indeed, that they typically could best preserve their own natural liberty by refraining from infringing that of others. Yet many individuals in the state of nature did not behave in accordance with this natural law reasoning about not injuring others. Moreover, in the state of nature, each individual was his or her own judge as to what natural law required and, further, had no protection against the depredations of others, except his or her own strength. As one American wrote, "because in such a state of nature, every man must be judge of the breach of the law of nature and executioner too (even in his own case) and the greater part being no strict observers of equity and justice; the enjoyment of property [including natural rights] in this state is not very safe. ${ }^{\circ 9}$ To avoid this insecurity, individuals, in accordance with the principle of self-preservation, sacrificed a portion of their natural liberty to civil government; they gave up some natural liberty in order to enable government

68. See LOCKE, TREATISES, supra note 37 , at $288-89$ (bk. II, ch. ï, $\S 6$ ):

But though this be a State of Liberty, yet it is not a State of Licence, though Man in that State have an uncontroleable Liberty, to dispose of his Person or Possessions yet he has not Liberty to destroy himself, or so much any Creature in his Possession, but where some nobler use, than its bare Preservation calls for it.

For an eighteenth-century American example, see statement of Iredell, supra note 61. Of course, the distinction continued to be used in the nineteenth century. For example, according to Nathaniel Chipman, "[n]o one is allowed to exercise this right [i.e., freedom of the press] so as to injure the right of another. It becomes necessary therefore to distinguish between the just liberty, and the licentiousness of the press." CHIPMAN, PRINCIPLES, supra note 48, at 104-05. See also id. at 105-06. Already in the eighteenth century, however, some Americans questioned this distinction. See, e.g., 8 ANNALS of CONG. 2140, 2142 (1798).

69. [ELISHA WILLIAMS?], THE ESSENTIAL RIGHTS AND LIBERTIES OF PROTESTANTS (1744), reprinted in POLITICAL SERMONS, supra note 30, at 57. Williams-if, indeed, he was the author-understood property in the broad, Lockean sense. In 1744, he was a member of Connecticut's General Assembly. At various times, he also taught at Yale and served on the Connecticut Supreme Court. 
to preserve the residue, a sacrifice accomplished by means of a constitution or contract of fundamental law. ${ }^{70}$ Although individuals were said to sacrifice some of their natural liberty to obtain protection from government, there was a danger that government could limit natural liberty more than was necessary for this purpose and that government might thereby become a threat to the very natural liberty it was designed to secure. ${ }^{71}$ For this reason, the people had to stipulate

70. That individuals "give up a part of their natural rights to secure the rest" was said to be "an old hackneyed and well known principle." Letter from William Pierce to St. George Tucker, GA. ST. GAZ., Sept. 28,1787 , reprinted in 16 DOCUMENTARY HISTORY OF THE CONSTTTUTION, supra note 39, at 443. According to John Jay, "the people must cede to [government] some of their natural rights, in order to vest it with requisite powers." THE FEDERALIST No. 2, at 37 (John Jay) (Clinton Rossiter ed., 1961). Chipman wrote:

That Man, on entering into civil society, of necessity, sacrifices a part of his natural liberty, has

been pretty universally taken for granted by writers on government. They seem, in general, not

to have admitted a doubt of the truth of the proposition. One feels as though it was treading on

forbidden ground, to attempt a refutation of what has been advanced by a Locke, a Bacari[a],

and some other eminent writers and statesmen.

CHIPMAN, SKETCHES, supra note 48, at 70. According to the town of Preston, "[w]e are willing to give up such share of our rights as to enable govemment to support, defend, and preserve the rest." Instructions of the Town of Preston, Conn. (Nov. 27, 1787), in 3 DOCUMENTARY HISTORY OF THE CONSTITUTION, supra note 39, at 439 . Paine discussed natural rights in terms of property; he wrote of "man" that "he finds it necessary to surrender up a part of his property to furnish means for the protection of the rest." THOMAS PAINE, COMMON SENSE 65 (Isaac Kramnick ed., 1986) (1776). Recalling a Federalist complaint about an amendment that senators be eligible for only six years in any term of twelve years, a leading Anti-Federalist said that:

[I]t was observed by an honorable member from New York, that this amendment would be an infringement on the natural rights of the people. I humbly conceive, if the gentleman reflects maturely on the nature of his argument, he will acknowledge its weakness. What is government itself but a restraint upon the natural rights of the people? What constitution was ever devised that did not operate as a restraint on their original liberties?

2 ELLIOT'S DEBATES, supra note 39, at 311 (statement of Melancton Smith in N.Y. Ratification Convention). In the North Carolina ratification debates, Spencer said: "When individuals enter into society, they give up some rights to secure the rest." 4 ELLIOT'S DEBATES, supra note 39, at 153 (statement of Joseph Spencer in N.C. Ratification Convention). The Anti-Federalist essayist, "Brutus," wrote:

But it is not necessary ... that individuals should relinquish all their natural rights. Some are of such a nature that they cannot be surrendered. Of this kind are the rights of conscience, the right of enjoying and defending life, etc. Others are not necessary to be resigned, in order to attain the end for which government is instituted, these therefore ought not to be given up .... From these observations it appears, that in forming a government on its true principles, the foundation should be laid in the manner I before stated, by expressly reserving to the people such of their essential natural rights, as are not necessary to be parted with.

"Brutus," N.Y. J., Oct. 1787-Apr. 1788, reprinted in 2 THE COMPLETE ANTI-FEDERALIST, supra note 37, at 373; see also, e.g., "AN OLD WHIG," reprinted in 3 THE COMPLETE ANTI-FEDERALIST, supra note 37, at 33; WITHERSPOON, supra note 25, at 123 (Lecture X); 2 THE WORKS OF JAMES WILSON, supra note 41, at 587.

Commenting on the language used to discuss the sacrifice of natural liberty, Theophilus Parsons wrote: "Sometimes we shall mention the surrendering of a power to controul cur natural rights, which perhaps is speaking with more precision, than when we use the expression of parting with natural rights-but the same thing is intended." THEOPHIIUS PARSONS, THE ESSEX RESULT (1778), reprinted in MEMOR OF THEOPHILUS PARSONS 365 (Theophilus Parsons, [Jr.] ed., 1859).

71. In the words of a leading Anti-Federalist:

But rulers have the same propensities as other men; they are as likely to use the power with which they are vested for private purposes, and to the injury and oppression of those over whom they are placed, as individuals in a state of nature are to injure and oppress one another. It is therefore as proper that bounds should be set to their authority, as that govemment should have at first been instituted to restrain private injuries.

"Brutus," N.Y. J., Oct. 1787-Apr. 1788, reprinted in 2 THE COMPLETE ANTI-FEDERALIST, supra note 37, at 373 . 
in their constitution which natural rights were sacrificed and which were not, ${ }^{72}$ it being important for the people to retain those portions of their natural liberty that were inalienable, that facilitated the preservation of freedom, or that simply did not need to be given up. ${ }^{73}$

Americans who discussed natural liberty and constitutions typically assumed that only such natural liberty as was reserved by a constitution would be a constitutional right. ${ }^{74}$ Even though they said that some portions of natural liberty were inalienable and therefore ought not to be infringed, ${ }^{75}$ they tended to consider a government's infringement of an inalienable right a reason for questioning the legitimacy of the legal system that permitted such a violation rather than a basis for making a claim through such a system. ${ }^{76}$ Consequently,

72. It was also for this reason-to protect natural rights from government-that constitutions had to be clear and even, perhaps, somewhat particular.

A people, entering into society, surrender such a part of their natural rights, as shall be necessary for the existence of that society. .. . They are conveyed by a written compact, expressing those which are given up, and the mode in which those reserved shall be secured. Language is so easy of explanation, and so difficult is it by words to convey exact ideas, that the party to be governed cannot be too explicit. The line cannot be drawn with too much precision and accuracy.

"John DeWitt," AM. HERALD, Oct.-Dec. 1787, reprinted in 4 THE COMPLETE ANTI-FEDERALIST, supra note 37, at 21. See also statement of "Brutus," supra note 70.

73. See Berns, supra note 7; see also Michael, supra note 7.

74. For example, on the commencement of the New Hampshire Constitution, the Rev. McClintock preached: "Were it necessary, I might shew with what precision the rights belonging to men in a state of society are defined in the Declaration of Rights, and the life, liberty and property of the subject guarded with a jealous care against oppressive power ...." SAMUEL MCCLINTOCK, A SERMON 23-24 (1784) (Evans $18,567)$. The converse of this was, as Jefferson wrote, that "our rulers can have no authority over such natural rights, only as we have submitted to them." THOMAS JEFFERSON, NOTES ON THE STATE OF VIRGINIA (1784), reprinted in JEFFERSON, WRITINGS, supra note 57, at 274-75 (Query 17).

Earlier writers had sometimes said that individuals in the state of nature "exchanged" their natural rights for civil rights, and Americans could use this rhetoric in a way that emphasized the role of constitutions and other civil laws. Zephaniah Swift of Connecticut said: "Natural and civil rights cannot be enjoyed at the same time. We must give up the one to attain the other." 1 SwIFr, supra note 60 , at 16 . In other words, under civil government, an individual has only such rights as are acknowledged by the civil laws-his civil rights. For a much later example, see HENRY ST. GEORGE TUCKER, A FEW LECTURES ON NATURAL LAW 54 (1844).

75. Thus, inalienable natural rights were distinguishable from constitutional rights. For example, the "Federal Farmer" said of rights that "some are natural and unalienable, of which even the people cannot deprive individuals: Some are constitutional or fundamental; these cannot be altered or abolished by the ordinary laws; but the people, by express acts, may alter or abolish them." "FEDERAL FARMER" (Dec. 25, 1787), reprinted in 2 THE COMPLETE ANTI-FEDERALIST, supra note 37, at 261.

76. A failure of a constitution adequately to protect natural liberty was to be remedied by altering the constitution. For example, the Virginia Declaration of Rights proclaimed:

That Government is, or ought to be, instituted for the common Benefit, Protection, and Security, of the People, Nation, or Community; of all the various Modes and Forms of Government that is best, which is capable of producing the greatest Degree of Happiness and Safety and is most effectually secured against the Danger of Mal-administration; and that, whenever any Government shall be found inadequate or contrary to these Purposes, a Majority of the Community hath an indubitable, unalienable, and indefeasible Right, to reform, alter, or abolish it, in such Manner as shall be judged conducive to the public Weal.

Va. Decl. of Rights of $1776 \$ 3$. Similarly, the Massachusetts Constitution declared:

The end of the institution, maintenance and administration of government, is to secure the existence of the body-politic; to protect it; and to furnish the individuals who compose it, with the power of enjoying, in safety and tranquility, their natural rights, and the blessings of life: And whenever these great objects are not obtained, the people have a right to alter the government, and to take measures necessary for their safety, prosperity and happiness. 
for legal restraints on the power of government, they depended upon constitutions. This dependence upon constitutions for the reservation of natural rights was a premise of the fears of Anti-Federalists, one of whom exclaimed:

\author{
If a citizen of Maryland can have no benefit of his own bill of rights \\ in the confederal courts, and there is no bill of rights of the United \\ States-how could he take advantage of a natural right founded in
}

MASs CONST. of 1780 , pmbl. The North Carolina Constitution began: "Whereas allegiance and protection are, in their nature, reciprocal, and the one should of right be refused when the other is withdrawn. ..." N.C. CONST. of 1776, pmbl. According to Rev. Hemmenway:

[N]o man has ever any rightful liberty to consent to any constitution or compact inconsistent with his own safety and welfare, and that of his fellow men; for instance, to authorize any to govern unrighteously and oppressively. . . . and if any people have been so imprudent and blameable as to consent to, and put themselves under a tyrannical government, they are so far from being bound in honor or conscience to support it, that it is their duty to overthrow and abolish it as soon as they can.

HEMMENWAY, supra note 61, at 14-15 (Mass. election sermon 1784) (Evans 18,526).

So too, the remedy for a constitution that did not conform to the law of nature was to alter it. According to the 1791 Massachusetts election sermon:

There is a fixed, unalterable rule, by which the measure of obedience to rulers, is to be determined - that is, while they regulate their administration by the immutable laws of morality, and by the constitution and laws of the State-Or, in other words, while they act agreeably to the original design of all govemment, the good of the governed.-So long is obedience a duty, and no longer.

When those in power, so far lose sight of this object, as to enact laws, and require obedience, in violation of the constitution, or of the laws of GOD, in such a case, obedience would be rebellion against Heaven, and implicit treason against the State.

CHANDLER ROBBINS, A SERMON 27-28 (Mass. election sermon 1791) (Evans 23,741). On the other hand, in the aftermath of Shays's Rebellion, it was useful to distinguish between resistance by the people and by a small portion thereof:

All power originating in the people, will, by no means justify individuals, or a small part of the community, in refusing obedience to laws which they may think oppressive.-They have an indisputable right, with a decent, and manly firmness, to represent their grievances, and to remonstrate to government, in a suitable manner.

Id.

For a discussion of the possibility that Americans at a slightly later date thought they could judicially enforce imperfect natural rights as constitutional law, see CHARLES G. HAINES, THE REVIVAL OF NATURAL LAW CONCEPTS 86-103 (1930). In many of the cases cited by Haines, however, the judges appear to have assumed that they were applying principles or rights that were impliedly part of the constitutional contract - whether implied by the character of the contract or by the reasons the people entered it. In other words, on the basis of the natural rights or contract analysis, these judges argued that the people could not, in the absence of express provisions to the contrary, be presumed to have sacrificed certain natural rights. In Calder v. Bull, for example, Justice Chase said that

[t]he purposes for which men enter into society will determine the nature and terms of the social compact .... The nature, and ends of legislative power will limit the exercise of it. ... An ACT of the Legislature (for I cannot call it a law), contrary to the great first principles of the social compact, cannot be considered a rightful exercise of legislative authority. . . . To maintain that our Federal, or State, Legislature possesses such powers, if they had not been expressly restrained, would, in my opinion, be a political heresy, altogether inadmissable in our free republican governments.

Calder v. Bull, 3 U.S. (3 Dall.) 386, 388-89 (1798). Natural rights theorists had long discussed contracts, imcluding contracts of government, and had suggested rules of interpretation. Among other things, they wrote about the importance of the reason or purpose of contracts or of laws. Justice Chase began to expand upon and develop these and similar, common law ideas in a way that appeared to Iredell and others to undermine the express and written character of the Constitution.

For the later development of the natural rights analysis in a way that would have permitted judicial and even individual voiding of constitutional law, see infra note 133 . 
reason, could he plead it and produce Locke, Sydney, or Montesquieu as authority? ${ }^{77}$

A constitution that granted broad powers and failed to mention freedom of the press worried Anti-Federalists because "[t]he people's or the printers claim to a free press, is founded on the fundamental laws, that is, compacts, and state constitutions .... The people, who can annihilate or alter those constitutions, can annihilate or limit this right." ${ }^{\text {"78 }}$ Thus, according to Anti-Federalists, individuals had a legal right to the freedom of speech and press and their other natural liberties only to the degree they reserved these rights in their constitution

77. "A Farmer," MD. GAZ., Feb. 15, 1788, reprinied in 5 THE COMPLETE ANTI-FEDERALIST, supra note 37, at 9, 13. The clear implication was that the citizen could not. The "Farmer" continued: "How could he take advantage of any of the common law rights, which have heretofore been considered as the birthright of Englishmen and their descendants, could he plead them and produce the authority of the English judges in his support? Unquestionably not ...." 5 Id.; see also 5 id. at 11 .

78. "FEDERAL FARMER" (Jan. 20, 1788), reprinted in 2 THE COMPLETE ANTI-FEDERALIST, supra note 37, at 323, 329. The "Federal Farmer" also said:

To make declaratory articles unnecessary in an instrument of government, two circumstances must exist; the rights reserved must be indisputably so, and in their nature defined; the powers delegated to the government, must be precisely defined by the words that convey them, and clearly be of such extent and nature as that, by no reasonable construction, they can be made to invade the rights and prerogatives intended to be left in the people."

2 Id. at 325-26. Another wished "that the freedom of the press may be previously secured as a constitutional and unalienable right, and not left to the precarious care of popular privileges [i.e., public opinion about rights] which may or many not influence our new rulers." "CENCINNATUs" (Nov. 8, 1787), reprinted in 6 THE COMPLETE ANTI-FEDERALIST, supra note 37, at 10, 11.

Speaking of natural rights in general, the "Impartial Examiner" wrote:

There can be no other just origin of civil power, but some such mutual contract of all of the people: and although their great object in forming society is an intention to secure their natural rights; yet the relations arising from this political union create certain duties and obligations to the state, which require a sacrifice of some portion of those rights and of that exuberance of liberty, which obtains in a state of nature.-This, however, being compensated by certain other adventitious rights and privileges, which are acquired by the social connection .... [t]hey ought to give up no greater share than what is understood to be absolutely necessary:-and they should endeavor so to organize, arrange and connect it's several branches, that when duly exercised it may tend to promote the common good of all. ... It is evident, therefore that they should attend most diligently to those sacred rights, which they have received with their birth, and which can neither be retained to themselves, nor transmitted to their posterity, unless they are expressly reserved: for it is a maxim, I dare say, universally acknowledged, that when men establish a system of govemment, in granting the powers therein they are aiways understood to surrender whatever they do not so expressly reserve.

"Impartial Examiner," To the Free People of Virginia, VA. INDEP. CHRON. (Feb. 20, 1788), reprinted in 5 THE COMPLETE ANTI-FEDERALIST, supra note 37, at 173, 176; see also id. at 177, 185. According to "An Old Whig," "To define what portion of his natural liberty, the subject shall at all times be entitled to retain, is one great end of a bill of rights." "An Old Whig," INDEP. GAZETTER (Phila.) Oct. 1787-Feb. 1788, reprinted in 3 THE COMPLETE ANTI-FEDERALIST, supra note 37, at 30, 33. "Brutus" wrote that "the portion of their natural liberty, which they give up for the enjoyment of civil government, should be expressly mentioned, in the constitution." "Brutus," VA. J., Dec. 6, 1787, reprinted in 8 DOCUMENTARY HISTORY OF THE CONSTITUTION, supra note 39, at 212. Joseph Spencer wrote that "a Number of individual Rights must be given up to Society, but there should always be a memorial of those not surrendered, otherwise every natural \& domestic Right becomes alianable, which raises Tyranny at once, \& this is as necessary in one Form of Government as in another . . . " Letter from Joseph Spencer to James Madison (Feb. 28, 1788), in 16 DOCUMENTARY HISTORY OF THE CONSTITUTION, supra note 39, at 252, 253; see also Richard Henry Lee, VA. GAZ, Oct. 16, 1787, reprinted in 5 THE COMPLETE ANTI-FEDERALIST, supra note 37, at 114; 4 ELLIOT's DEBATES, supra note 39, at 152-53 (statement of Joseph Spencer in N.C. Ratification Convention). 
or, less securely, provided for them in other civil law. Federalists did not dispute this. Instead, they simply argued that the enumeration of federal powers in the unamended Constitution adequately reserved natural liberty and that the spirit of the people was a more important means of preserving rights than any paper guarantees. $^{79}$

In describing what portions of natural liberty would have constitutional protection, American constitutions appear to have referred to merely some of the freedom of speech and press possible in the state of nature. ${ }^{80}$ For example, as historians have pointed out, Americans frequently said or assumed that certain types of speech or press-including blasphemous, obscene, fraudulent, or defamatory words-lacked or should lack constitutional protection. ${ }^{81}$ True, Noah Webster argued against a constitutional amendment enumerating "the liberty of the Press" on the ground that the phrase could be interpreted to protect blasphemous or obscene material and, indeed, "every possible publication."

79. On paper guarantees, see 2 ELLIOT's DEBATES, supra note 39 , at 251 (statement of Alexander Hamilton in N.Y. Ratification Convention) (interests and opinions of men more important than parchment provisions); John Dickinson, LETTERS OF FABIUS, reprinted in PAMPHLETS ON THE CONSTITUTION OF THE UNITED STATES 186 (Paul L. Ford ed., 1968) [hereinafter PAMPHLETS] (liberties, such as trial by jury, secured by people's sense and honesty, not by bill of rights); THE FEDERALIST, No. 83, at 509 (Alexander Hamilton) (Clinton Rossiter ed., 1961) ("genius" of government is all that can be relied upon for permanent effects, not particular provisions of a constitution); THE FEDERALIST, No. 84, at 514 (Alexander Hamilton) (Clinton Rossiter ed., 1961) (free press depends upon public opinion and spirit of people and government); "Uncus," MD. J. (Nov. 9, 1787), reprinted in 14 DOCUMENTARY HISTORY OF THE CONSTITUTION, supra note 39, at 77-78,81 (virtue rather than bill of rights necessary to preserve liberty); Noah Webster, Government, 1 AM. MAG. 137, 140 (1788); Letter from James Madison to Thomas Jefferson (Oct. 17, 1788), in 11 MADISON PAPERS, supra note 38, at 295, 297 (noting that many think addition of a bill of rights is unnecessary or misplaced); Letter from G.L. Turberville to James Madison (June 16, 1789), in 12 MADISON PAPERS, supra note 38, at 224-25 (if people are seized by "depravity of manners," no document can save them).

80. Note that, by limiting federal authority, the U.S. Constitution's enumeration of federal powers was said to provide protection for part of the natural right of free speech and press. This protection for speech and press was broader, in some respects, than the protection provided by the First Amendment. As judicial expansion of federal power has trivialized the protection provided by the enumeration of powers, the First Amendment's protection of speech and press has come to seem our only or, at least, our most important constitutional limitation on federal contral of speech and press. See Philip A. Hamburger, Natural Rights and Positive Law: A Comment on Professor McAffee's Paper, 16 S. ILL. L.J. 307, 310-11 (1992).

81. See generally LeVY, supra note 14; NORMAN L. ROSENBERG, PROTECTING THE BEST MEN (1986).

82. Webster asked:

[W]ould you say, the liberty of the Press shall not be restrained? Well, what is this liberty of the Press? Is it an unlimited licence to publish any thing and every thing with impunity? If so, the Author, and Printer of any treatise, however obscene and blasphemous, will be screened from punishment. You know, Gentlemen, that there are books extant, so shockingly and infamously obscene and so daringly blasphemous, that no society on earth, would be vindicable in suffering the publishers to pass unpunished. You certainly know that such cases have happened, and may happen again-nay, you know that they are probable. Would not that indefinite expression, the liberty of the Press, extend to the justification of every possible publication? Yes, Gentlemen, you know, that under such a general licence, a man who should publish a treatise to prove his maker a knave, must be screened from legal punishment. I shudder at the thought!-But the truth must not be concealed. The Constitutions of several States guarantee that very licence.

"America" [Noah Webster], N.Y. DARY ADVERTISER, Dec. 31, 1787, reprinted in 15 DOCUMENTARY HISTORY OF THE CONSTTIUTION, supra note 39, at 194, 196. When defending the absence of a bill of rights in the U.S. Constitution, Hamilton also took this position: "What signifies a declaration that "the liberty of the press shall be inviolably preserved'? What is the liberty of the press? Who can give it any definition which would not leave the utmost latitude for evasion? I hold it to be impracticable. . . ." THE FEDERALIST No. 84, at 514 (Alexander Hamilton) (Clinton Rossiter ed., 1961). 
Yet he seems to have convinced few of his contemporaries that the phrase might justify such licentiousness. Americans included the phrase or variants of it in their constitutions and apparently tended to assume it would be correctly understood. When Americans feared otherwise-such as, most commonly, when they feared that their speech-and-press clauses would be interpreted to hinder actions and prosecutions for various forms of defamation-they carefully drafted their constitutions to eliminate this danger. ${ }^{83}$

Thus, only a portion of the natural right to speak and publish as one pleased was retained under civil governments. The freedom of speech and press was constitutionally protected from the government of an American state only to the degree that the state's constitution reserved that freedom. As Edmund Randolph noted when drafting the United States Constitution, "we are not working on the natural rights of men not yet gathered into society, but upon those rights, modified by society, interwoven with what we call the rights of states. ${ }^{184}$ As modified by society and interwoven with the rights of states-that is, as protected by the civil laws and, particularly, the constitutions of the

83. For example, in 1790 , Pennsylvania adopted a new constitution, the press clause of which said that "every citizen may freely speak, write, and print on any subject, being responsible for the abuse of that liberty." PA. CONST. of 1790, art. IX, § 7; see also DEL. CONST. of 1792, art. I, \& 5; KY. CONST. of 1799, art. X, $\$ 7$; KY. CONST. of 1792, art. XII, $\$ 7$. Other illustrations may be taken from the ratification of the Massachusetts Constitution of 1780 . The town of Chelsea urged the following addition to the sixteenth article of the bill of rights-the free press clause- of the 1780 Massachusetts Constitution: "But as its freedom is not such as to Exempt any printer or printers from being answerable for false Defamitory and abusive Publications." THE POPULAR SOURCES OF POLIICAL AUTHORITY, supra note 42, at 771. In the town of Dunstable, an "objection was the 16th article in said bill of rights as to the liberty of the press as there being no restraint thereon it may be made use of to the Dishoner of god by printing herasy and so forth and like wise injurious to private Charactors." Id. at 641 . Bewick voted to amend the article to read: "The Liberty of the Press is essential to the Security of Freedom in a State: it Shall not therefore be restrained in this Commonwealth, unless in Cases where it is extended to the abuse, or injury of Private Characters." Id. at 728. In the debates about the Federal Constitution, the North Carolina ratification convention declared, inter alia, that "every freeman ought to find a certain remedy, by recourse to the laws, for all injuries and wrongs he may receive in his person, property, or character." 4 ELLIOT's DEBATES, supra note 39, at 244. Indeed, reputation was sometimes said to be a natural right. See supra note 41 .

So too, when the drafters of state constitutions wanted a broader definition of freedom of speech and press than was traditional, they used language specifying the changes. For example, various states stipulated that truth was a justification and that the jury could decide the whole issue. See, e.g., DEL. CONST. of 1792, art. I, \$ 5; KY. CONST. of 1792, art. XII, § 8; PA. CONST. of 1790, art. IX, § 7; TENN. CONST. of 1796, art. XI, $\$ 19$. In response to Jefferson's draft for a Constitution of "Virginia"-i.e., Kentucky-Madison wrote: "The Exemption of the press from liability in every case for true facts, is . . . an innovation and as such ought to be well considered." James Madison, Observations on Jefferson's Draft of a Constitution for Virginia (Oct. 15, 1788), in 11 MADISON PAPERS, supra note 38, at 281, 293. Note that Jefferson wanted a declaration of rights in the U.S. Constitution to say: "The people shall not be deprived or abridged of their right to speak to write or otherwise to publish anything but false facts affecting injuriously the life, liberty, property or reputation of others or affecting the peace of the confederacy with foreign nations." Letter from Thomas Jefferson to James Madison (Aug. 28, 1789), in 15 PAPERS OF THOMAS JEFFERSON 367 (Julian P. Boyd et al eds., 1950-1990) [hereinafter JEFFERSON PAPERS]; see also Sedition Act, § 3, I Stat. 596, 597 (1798).

84. Edmund Randolph, Document of Committee of Detail, in 2 FEDERAL CONVENTION RECORDs, supra note 37, at 137. An Anti-Federalist perspective on this appeared in [Luther Martin?], Observations, in SUPPLEMENT TO FARRAND, supra note 25, at 291-92. For the most comprehensive discussion of how the Bill of Rights affected the rights of men "interwoven with . . . the rights of states," see Wilmarth, supra note 7. 
American states-freedom of speech and press was considerably less extensive than the liberty to speak and publish as one pleased.

\section{Natural LaW AND Civil LaW}

Although Americans assumed that constitutions and statutes were positive acts of the people, Americans said that they should adopt constitutions and, more generally, civil laws that reflected natural law reasoning about noninjurious behavior and the preservation of liberty. Yet, being only a very abstract manner of reasoning, natural law was typically not understood to require the adoption of a particular set of civil laws. Moreover, though considered immutable, natural law was understood to permit variations in civil laws to accommodate the different circumstances in which such laws would operate. Consequently, constitutions and other civil laws could restrain natural liberty in varying degrees and ways and, nonetheless, could still be said to comport with natural law.

The idea that civil law should reflect natural law had a distant foundation in medieval theories. When Americans said that constitutions and other civil laws should be drafted to reflect the principles of natural law, they were building upon the medieval tradition that lawmakers should formulate civil laws in accordance with natural law. Some Americans who discussed natural law went so far as to say that it consisted of "right reason."85

Yet, even with the old label of "right reason," Americans were not employing medieval notions of natural law, for they understood natural law within the context of their modern natural rights analysis. As already discussed, eighteenth-century Americans tended to describe natural law as founded upon assumptions about humans in the state of nature, particularly-if they were discussing political theory - the principles of equal freedom and self-preservation. On this basis, as has been seen, Americans asserted that the people, in accordance with the implications of natural law, should protect their natural liberty by establishing government and should formulate their constitutions and laws to reflect natural law-that is, to reflect the reasoning that led the people to create constitutions and laws. ${ }^{86}$

85. See, e.g., JAMES WLSON, Lectures on Law, in 1 WORKS OF JAMES WILSON, supra note 41, at 67 , 145 (citing Cicero).

86. Nathaniel Chipman, for example, wrote that "[t]he constitutional laws ought to have a certain relation to the laws of nature, and to be founded in principles derived solely from those laws." CHIPMAN, SKETCHES, supra note 48, at 118. He also said: "The constitution is no other than the fundamental laws made and ratified by such compact ...." Id. at 116. The constitution was a "mutual compact." Id. An Anti-Federalist from Kentucky, "Republicus," wrote that "government which tends not to secure the lives, liberties and properties of every individual of the community, as far as the law of reason would have done, is unjust and iniquitous and merits not the name of civil government." "Republicus," Essay, KY. GAZ., Feb. 16, 1788, reprinted in 5 THE COMPLETE ANTI-FEDERALIST, supra note 37, at 160,162; see also statement of "Republicus," infra note 92. In the more religious version of the analysis to be expected from a Congregationalist minister, the Rev. Goodrich argued:

The end ... and nature of civil govermment imply that it must have for its foundation, the principles and laws of truth, justice and righteousness, mercy and the fear of GOD; or it can never 
When saying that constitutions and other civil laws should be formulated to reflect natural law, Americans typically were not suggesting that natural law was a kind of constitutional law or a source for constitutional rights not protected by a written constitution. On the contrary, under modern natural rights analysis, constitutional law and natural law were quite distinct from one another and played very different roles. According to the modern account of natural rights, discussed above, individuals in the state of nature sought to preserve themselves

advance the happiness of mankind. For that mankind by uniting into society, and putting themselves under a common government, can promote their true interest, otherwise than by observing these laws, is ... contrary to reason . . . .

GOODRICH, supra note 55, at 11 (Conn. election sermon 1787) (Evans 20,393). After discussing the necessity of laws equally binding on each individual, the Rev. Timothy Stone said: "A constitution, founded upon the general and immutable laws of righteousness and benevolence, and corresponding to their particular circumstances, will therefore become a primary object with a wise and understanding people." TIMOTHY STONE, A SERMON 11 (Conn. election sermon 1792) (Evans 24,820). The Rev. Williams preached: Almighty God, as Head of the System, and Supreme Governor of the Universe, will suitably animadvert upon every ... Violation of these immutable Laws of Equity, to vindicate his own Right, and inflict adequate Punishment on the Invader; not from a Spirit of Revenge, - or to cause Misery for it's own Sake;- but to inflict such Penalties, as will probably prevent future Injuries, and render Mens Right and Properties, as secure as they were before this dangerous Example of Injustice. In civil Society this Right, is in general, transfer'd to the Body, or Government, who have a Right, and it is their Duty, to punish those Violations of the Laws of Nature, whereby the People's Properties are injured. Every Society has a Right to publish, and execute equitable Laws and Rules, for the civil Order, Peace and Welfare of the People;-for ascertaining and securing their Rights and Properties, with suitable Penalties to the Transgressors: Which Laws are, or ever ought to be, only the Laws of Nature explained and applied, both Laws and Sanctions being founded in Reason and Equity. Things unreasonable, or absolutely indifferent (if such there be) ought not to be imposed by Law.

WILLIAMS, supra note 48, 9-10 (Mass. election sermon 1762) (Evans 9310). According to the Rev. Hemmenway:

Notwithstanding what has been so boldly pretended by some, of the transcendent authority, and omnipotency of the supreme civil power, and of those who are intrusted with the administration of government, it is plain that the whole authority of a state over its members is limited. The liberty and authority of a free commonwealth to enact and execute laws and ordinances for the public good, must be always understood with this limitation, viz-that the sacred rules of righteousness are not to be violated at any rate. The liberty and sovereignty of a state implies no right or authority to serve its own interest by unjust or immoral measures; even though such measures should be thought for the public advantage. It has no rightful liberty, under any such pretence, to violate the laws of GoD, or the rights of any of its members, to oppress or injure any of its neighbours, or falsify the public faith.

HEMMENWAY, supra note 61, at 18 (Mass. election sermon 1784) (Evans 18,526 ).

These notions of natural law occasionally drew on moralizing continental writings conceming natural law. The ideas propagated by these continental texts are particularly apparent in occasional assertions that legislation, including commercial legislation, should be in accord with "equity." According to the Rev. Benjamin Lord:

[IIt is always the Duty of the civil Legislature to conform to the Word of God, (the great Standand of Truth, and Measure of Right and Wrong) in all their Laws, of however minute Consequence: For, still, all must be designed for, and therefore in their Nature directed to, the good of the whole Community. And therefore, have nothing unwise, unjust and Oppressive in them; even the Laws which order Labour, as well as Money, for the common Good, should distribute the same in such a proportion as agrees well with Equity. And so all Precepts \& Orders with respect to Merchandize \& Trade, and the Medium thereof should be in a strict Conformity to the fundamental Laws of Justice and Equity. This, being the Bottom, on which only the State can safely stand. Yea, in every Act of the Legislature, utmost Care must be had, that there be no Unrighteousness and Oppression bor'n [sic] with, much less countenanced and encouraged by public Authority.

BENIAMIN LORD, RELIGION AND GOVERNMENT SUBSISTING TOGETHER IN SOCIETY 24-25 (Conn. election sermon 1751) (Evans 6868). 
and their liberty by establishing government through a constitution or contract of fundamental law. This model-most notably the versions elaborated by some continental writers-had a strong appeal for eighteenth-century Americans interested in constitutions. ${ }^{87}$ Whereas Englishmen had to find their constitutional contract in common-law custom and increasingly had to recognize the absence of any but self-imposed restraints on Parliament, Americans could observe in their various charters and, later, constitutions more tangible examples of the contract of government. Already in the 1770's, the state-of-nature or modern natural rights analysis appears to have been the dominant theoretical justification for revolution and written constitutions. ${ }^{88}$ In the American understanding of

87. The analysis of Locke was particularly useful for its treatment of revolution, but continental theory and derivative English analysis more explicitly posited written constitutions of fundamental law.

88. Another point of view, that Americans desired or assumed a partially unwritten constitution, has been advanced by, among others, BAllYN, supra note 3; WOOD, supra note 3; Grey, Do We Have an Unwritten Constitution?, supra note 3, at 715-16; Sherry, supra note 3. This perspective, however, has been called into question by the works of various historians, including the following: PETERS, supra note 7, at 1-13; WHITE, supra note 44; Berns, supra note 7; Kramnick, supra note 23; Michael, supra note 7; Rothman, supra note 27; see also CHARLES E. MERRIAM, A HISTORY OF AMERICAN POLITICAL THEORIES 47 (photo. reprint 1969) (1903); Gary J. Schmitt \& Robert H. Webking, Revolutionaries, Antifederalists, and Federalists: Comments on Gordon Wood's Understanding of the American Founding, 9 POL. SCI. REV. 195 (1979).

This is not the place to review all of the evidence. Suffice it to say that the vast weight of evidence from American writings of the 1770's and 1780's appears to support the position taken here. Consider the following examples of contract analysis. In 1771, John Tucker preached that "the fundamental laws, which are the basis of government, and form the political constitution of the state, 一 which make out, and fix the chief lines and boundaries between the authority of Rulers, and the liberties and privileges of the people, are, and can be no other, in a free state, than what are mutually agreed upon and consented to." JOHN TUCKER, AN ELECTION SERMON (1771), reprinted in I AMERICAN POLITICAL WRITING, supra note 29, at 162. After urging that a "continental conference" should meet, Thomas Paine said that "their business" should "be to frame a CONTINENTAL CHARTER, or Charter of the United Colonies; (answering to what is called the Magna Charta of England) fixing the number and manner of choosing members of Congress, members of Assembly ... Securing freedom and property to all men, and above all things the free exercise of religion, according to the dictates of conscience ...." PAINE, supra note 70, at 97. This charter was a "constitution." Id. at 98; see also id. at 109. The Maryland Constitution declared "that all government of right originates from the people, is founded in compact only, and instituted soley for the good of the whole." MD. CoNST. of 1776, DECL. OF RIGHTS art. I. In 1788, Thomas Reese-a Presbyterian minister in Salem, South Carolina-wrote: "If Mr. Locke, and the American politicians, argue right, all legitimate government is originally founded on compact." THOMAS REESE, AN ESSAY ON THE INFLUENCE OF RELIGION IN CIVIL SOCIETY 20 (1788) (Evans 21,418). The Virginia legislature resolved

that when the former constitution or social compact of this Country \& the Civil Laws which existed under it, were dissolved-a Majority of the Inhabitants had through necessity, an unquestionable natural right to frame a new social compact \& to admit as parties thereto, those only who would be bound by the Laws of the Majority . . .

Instruction to Virginia Delegates in re Confiscated Property (Dec. 17, 1782), in 5 MADISON PAPERS, supra note 38, at 409. In South Carolina, it was written: "The constitution is a social covenant entered into by express consent of the people, upon a footing of the most perfect equality with respect to every civil liberty." "PHLODEMUS" [THOMAS TUDOR TUCKER], CONCILIATORY HINTS (1784), reprinted in 1 AMERICAN POLITICAL WRITING, supra note 29 , at 612 . On the commencement of the New Hampshire Constitution, the Rev. McClintock preached: "Were it necessary, I might shew with what precision the rights belonging to men in a state of society are defined in the Declaration of Rights, and the life, liberty and property of the subject guanded with a jealous care against oppressive power ...." MCCLINTOCK, supra note 74, at 23-24 (1784) (Evans 18,567). Witherspoon said: "Society I would define to be an association or compact of any number of persons, to deliver up or abridge some part of their natural rights, in order to have the strength of the united body, to protect the remaining, and to bestow others." WITHERSPOON, supra note 25, at 123 (Lecture $X$ ). In 1793, Nathaniel Chipman wrote that "it is now, in every free \& enlightened nation, admitted as fundamental, that all legitimate government originates in the free consent of the people; that to produce a rightful govemment, the people, among themselves, must enter into a mutual compact for that end." CHIPMAN, 
this analysis, "[t]he constitution, or whole social compact, is," in the words of a leading Anti-Federalist, "but one instrument, no more or less, than a certain number of articles, or stipulations agreed to by the people, whether it consist of articles, sections, chapters, bills of rights, or parts of any other denomination cannot be material. ${ }^{\circ 99}$ Whereas natural law was an unwritten and divinely sanctioned mode of reasoning from assumptions about humans in the state of nature, constitutional law was the created—and, in America, the written-product of men. ${ }^{90}$

Although Americans assumed that the people adopted a constitution and formed government in accordance with the natural law principles of equal liberty and self-preservation, Americans understood that the people might adopt a constitution that did not adequately preserve their natural liberty or that otherwise failed to conform to the implications of natural law. In analyzing this type of failure, however, Americans tended to say that the people had a right and a responsibility to alter their constitution, either by amendment or, if necessary, by revolution. ${ }^{91}$ Far from being a form of constitutional law, natural law typically was assumed to be the reasoning on the basis of which individuals adopted constitutions and a means by which the people could measure the adequacy of their constitutions. A failure of a constitution to reflect natural law was a ground for altering or abandoning the constitution rather than for making a claim in court.

Not only did Americans tend to consider natural law a prudential or moral guide rather than a substitute for constitutional law, but also, typically, they assumed that natural law did not clearly direct adoption of a particular set of civil laws. Just as natural law usually was understood to prohibit injury but not

SKETCHES, supra note 48, at 115-16. Also: "In the exercise of this right of free consent by the people . . . constitutions of government are formed. The constitution is no other than the fundamental laws made and ratified by such compact ...."Id. For other references to the Constitution or constitutions generally as compacts, see: CONG. REGISTER (June 8, 1789), reprinted in CREATING THE BILL OF RIGHTS, supra note 39, at 81 (remarks of James Madison); 3 ELLIOT'S DEBATES, supra note 39, at 449 (statement of Grayson in Va. Ratification Convention); "JOHN DE WITT," To THE FREE CITIENS OF THE COMMONWEALTH OF MASSACHUSETTS (1787) reprinted in 4 THE COMPLETE ANTI-FEDERALIST, supra note 37, at 21-2: "FEDERAL FARMER" (Oct. 9, 1787), reprinted in 2 THE COMPLETE ANTI-FEDERALIST, supra note 37, at 232, 323; "A Farmer," Essay, MD. GAZETTE, Feb. 15, 1788, reprinted in 5 THE COMPLETE ANTI-FEDERALIST, supra note 37, at 11; "The Impartial Examiner," Letter, VA. INDEP. CHRON., Feb. 20, 1788, reprinted in 5 THE COMPLETE ANTI-FEDERALIST, supra note 37, at 175.

Anti-Federalists had frequent occasion to discuss the sacrifice of natural rights under a written constitution. For some examples, see supra note 78 and accompanying text.

Although a vast number of Americans appear to have accepted the contract analysis, some preferred to say simply that a constitution was the declaration or act of the people. This alternative description of a constitution, however, was often in accord with other aspects of the contract theory.

89. "FEDERAL FARMER" (Jan. 20, 1788), reprinted in 2 THE COMPLETE ANTI-FEDERALIST, supra note 37 , at $214,323$.

90. In the words of the Massachusetts minister John Tucker, "the very being, and form of government, with all its constitutional laws, being thus from the people, hence civil government, is called, and with great propriety, the ordinance of man,--an human institution." JOHN TUCKER, AN ELECTION SERMON (1771) reprinted in 1 AMERICAN POLITICAL WRITING, supra note 29, at 158, 163.

91. See Berns, supra note 7; Michael, supra note 7; see also supra note 76 and accompanying text. 
to dictate an individual's choice of noninjurious actions, so too natural law usually was understood to permit nations much freedom in forming their constitutions and laws. Congregational clergymen, who were inclined to emphasize the breadth of natural law's moral implications and the importance of natural law as a moral foundation for civil law, acknowledged that constitutions and other civil laws had to vary according to circumstances. ${ }^{92}$ Such circumstances might require changes over time as well as from place to place. ${ }^{93}$ Natural law might be fixed in the nature of the physical world, ${ }^{94}$ but

92. Rev. Lord preached:

For, tho' no particular Form of Government, or Mode of Administration, is precisely determin'd by Reason or Scripture, for all particular Communities; but, this, left rather to be variously determined by the Prudence and Policy of different Kingdoms and civil Polities; according as best suits their particular Circumstances and Interests: Yet, some Form or other is necessary; and in general, It seems, that all civil Government of the right Stamp, must be agreeable to Scripture and Reason, and so to the Nature and Ends of a civil Community, the Preservation of the Lives, Liberties \& Estates of all the Members thereof, against the force of Rapine, Injustice $\&$ all manner of destructive Violence.

LORD, supra note 86, at 28 (Conn. election sermon 1752) (Evans 6868). The Rev. Clark said:

That a little acquaintance with the world and the history of mankind, in the several ages past, will clearly decide, that no one constitution, or form of civil government, can be supposed to be equally adapted to answer the best purposes of such an institution, in every society, nation or state.

ClARK, supra note 37, at 12-13 (Mass. election sermon 1781) (Evans 17,114). According to the Rev. Goodrich:

The great laws of justice must be armed with a civil force, and never allowed to be transgressed with impunity. Such, for instance, is that statute . . . "Ye shall do no unrighteousness; in judgement, in mete-yard, in weight or in measure. Just balances, just weights, a just ephah, and a just hin, shall ye have." This law must be admitted into every civil state; but, that it may have force in society, the public standard must be fixed; the most convenient weights and measures, determined; the manner of their being tried, ascertained; and an awful penalty annexed to transgression. These are circumstances, which are not determined by the law of nature; but must be adjusted by civil regulations suited to the condition of particular commonwealths.

GOODRICH, supra note 55, at 14-15 (Conn. election sermon 1787) (Evans 20,393). After associating reason with conformity to natural law, an Anti-Federalist wrote that "mankind found it necessary to enter into solemn compacts of mutual defence, and security, and in those compacts, to establish certain rules, founded upon, or at least agreeable to, the universal reason of mankind, (the common law of nature) to which they should all be equally subject." "Republicus," KY. GAZ., Feb. 16, 1788, reprinted in 5 THE COMPLETE ANTIFEDERALIST, supra note 37 , at 160,162 . Of course, such opinions were hardly confined to America. For example, Chancellor Henley wrote in his commonplace book that the "Law of Nature is perfect, Immutable, \& etemal." In contrast, "It]he Civil Law is a law instituted by a particular set of people \& peculiar to them." It "is not in all things Consonant to ye Law of Nature \& Nations, nor is it opposite to them. It is mutable being chang'd by disuse [of] ye Laws[,] Consent of the People, or by a Publick Act of Repeal." Henley's Commonplace Book, British Library, Add. 26060, ff. 14v-15r.

In addition, note that many Americans, like Locke and earlier writers, sometimes denied that "God's law" ordained a particular form of government. See, e.g., JOSIAH BRIDGE, A SERMON 9 (Mass. election sermon 1789) (Evans 21,713); JOSIAH WHITNEY, THE ESSENTIAL REQUISITES TO FORM THE GOOD RULER'S CHARACTER 12 (Conn. election sermon 1788) (Evans 21,601). These writers on civil government would have been aware of the sixteenth- and seventeenth-century Anglican apologists who had argued that neither natural law nor divine law dictated one particular form of church government. See, e.g., RICHARD HOOKER, OF THE LAWS OF ECCLESIASTICAL POLITY (J.M. Dent \& Sons Ltd. 1907) (originally published in installments between 1593 and 1662); EDWARD STLLINGFLEET, IRENICUM (rev. ed. 1662) (1659).

93. The Rev. Clark preached:

That in the rise and progress of society, different modes of government have been adopted and introduced, at different stages and successive periods, cannot be doubted.-And whether there hath not been, in many instances, at least, a gradation in the modes of government, keeping pace with the progress of society, in the several ages of the world, similar to that gradation, which is easily observed in the several stages and periods of human life .... 
it left great latitude to human societies, which could adopt widely differing civil laws and could dramatically alter their civil laws without departing from the implications of natural law.

Indeed, civil laws frequently had to impose greater restraints than natural law, for, even if somehow directly adopted in civil laws, natural law was, by itself, quite inadequate. Commentators had long observed that natural law was so general and so imprecise that it invited a variety of conflicting opinions about its requirements. ${ }^{95}$ Therefore, they said, civil laws had to provide details and

... [H]ave we not seen, in various instances, a people emerging from a state of nature, and perhaps obscurity, with all the life, vigor, heat and zeal, as well as undisguised simplicity of youth, entering into society ....

CLARK, supra note 37, at 13 (Mass. election sermon 1781) (Evans 17,114). Clark also said:

Certain it is, that as different societies and states may require different modes of government; so the same societies or nations may require different constitutions, at distinct and distant periods and stages of their existence.

$\cdots$

Upon the whole, the propriety or impropriety of this or that constitution or mode of government, for this people or another, depends upon a variety of circumstances; such as character, situation, manners, customs, trade, connections, \&cc.- of which the people, are, or, most certainly, ought to be the best, if not the only competent judges.

Id. at 16-17. According to Goodrich:

The principles and laws of justice are fixed and unchangeable-they depend not on human authority; but the particular regulations, by which they have force in society, as civil laws, not being determined by the law of nature, may be changed, when they are found inconvenient and hurful to the community....

Nevertheless, great care should be taken in framing laws, that they may be suited to the peculiar state of a people, and have an equal and uniform operation for the public good. New and different circumstances require new and different regulations in society, fitted to the occasions which produce them ....

GOODRICH, supra note 55, at 15-16 (Conn. election sermon 1787) (Evans 20,393). Goodrich also said, however:

New and different circumstances require new and different regulations in society, fitted to the occasions which produce them: But the fundamental laws, by which a people are compacted together, like the laws of the natural world, must have a fixed consistence and duration. Such, in general, are laws relating to personal liberty, the privileges of the subject, and the powers of the magistrate - to private property and the execution of justice- to the punishment of evil-doers and the preservation of the public peace-to marriage, education, religion, and the rights of conscience-to the public forms, and order of govemment-and to the revenues and taxes, by which the state is supported.

Id. at 15-16.

Although Americans could use this analysis to suggest that even constitutions would have to change, they tended to distinguish between laws that would have to change with new circumstances and laws that could be permanent. Typically, they assumed that constitutions should be permanent, and Federalists in 1787 and 1788 even argued that constitutions should be drafted to avoid the necessity of alterations over time. See Philip A. Hamburger, The Constitution's Accommodation of Social Change, 88 MICH. L. REV. 239 (1989).

94. See GOODRICH, supra note 55, at 8 (Conn. election sermon 1787) (Evans 20,393) ("They are as fixed and unchangeable as the laws which operate in the natural world."); see also CHIPMAN, SKETCHES, supra note 48 , at 283 . WILSON, Lectures on Law, reprinted in 2 WORKS OF JAMES WILSON, supra note 41, at 293.

95. According to Samuel Parker, "too many Men that are bold and confident call every thing the Law of Nature that they have a mind or fancy to, without being bound to give any Proof of its Reasonableness or Account of its Obligation; it is no more but calling it the Law written in their Hearts, and then it must right or wrong pass for the Universal Law of Mankind...." PARKER, supra note 65, at 6. Locke incorporated similar ideas into his explanation of the necessity of establishing government:

[T] he Law of Nature being unwritten, and so no where to be found but in the minds of Men, they who through Passion or Interest shall mis-cite, or misapply it, cannot so easily be convinced of their mistake where there is no establish'd Judge: And so it serves not, as it ought, to determine 


\section{clarity absent from natural law. ${ }^{96}$ Natural law was also inefficacious. Sadly,}

the Rights, and fence the Properties of those that live under it, especially where every one is Judge, Interpreter, and Executioner of it too, and that in his own Case: . . . To avoid these Inconveniences .... Men unite into Societies, that they may have the united strength . . . and may have standing Rules to bound it, by which every one may know what is his . . that they shall be govem'd by declared Laws, or else their Peace, Quiet, and Property will still be at the same uncertainty, as it was in the state of Nature.

LOCKE, TREATISES, supra note 37 , at $376-77$ (bk. II, ch. xi, $\$ 136$ ). Jefferson observed:

Those who write treatises of natural law, can only declare what their own moral sense and reason dictate in the several cases they state. Such of them as happen to have feelings and a reason coincident with those of the wise and honest part of mankind, are respected and quoted as witnesses of what is morally right or wrong in particular cases. Grotius. Puffendorf, Wolf, and Vattel are of this number. Where they agree their authority is strong; but where they differ (and they often differ), we must ... decide between them.

Thomas Jefferson, Opinion on the question whether the United States have a right to renounce their treaties with France (Apr. 28, 1793), in JEFFERSON, WRITINGS, supra note 57, at 319.

96. According to Witherspoon, "[a] number of things in this view may become illegal, which before were not immoral." WITHERSPOON, supra note 25, at 163 (Lecture XTV). Yet he also said: "There are degrees of every crime--profanity, impurity, violence, slander, that are blameable in point of morals ... that if they were made cognizable by the civil magistrate, would multiply laws and trials beyond measure." Id. "Republicus" - an Anti-Federalist from Kenucky-wrote:

[A] universal, and unerring observation of, and obedience to this law [of nature], is what we call rectitude, or moral virtue: which, where it prevails, necessarily precludes all civil government; which is only substituted in the room of the aforesaid natural law, where its principles are not duly attended to, or its sanctions appear too distant, or feble .... But it is not only necessary that government should be formed on principles of equal right; but also that those principles should be precisely delineated and guarantied by the most solemn sanctions. This if you please we will call a constitution.

"Republicus," KY. GAZ., Feb. 16, 1788, reprinted in 5 THE COMPLETE ANTI-FEDERALIST, supra note 37, at 160,161-62. Of reason and conscience, Wilson said that "at some times, their admonitions are not sufficiently clear . . . ." WLSON, Lectures on Law, reprinted in 2 WORKS OF JAMES WILSON, supra note 41, at 143 . He also said: "True it is, that, by the municipal law, some things may be prohibited, which are not prohibited by the Law of nature ...." 2 Id. at 587. Zephaniah Swift wrote:

Every member of the society submits to numerous restraints upon his conduct, which are not required by the moral law .... We submit to many formalities respecting contracts, which are the offspring of positive, and not of natural law, to render our property secure. We consent to be restrained from doing many acts which are innocent in themselves, and to be obliged to do many acts which the natural state does not require, to obtain compleat protection for the acts we mean to enjoy."

1 SWIFT, supra note 60 , at 16; see also 1 id. at 38 .

However, natural law could also be understood as too extensive to be enforced by civil authorities. Taking natural law to be a complete account of the "social" obligations of morality-the moral duties owed to other humans-the Rev. Goodrich argued that civil law could not and should not define and put sanctions on all moral obligations:

[I]n all well regulated civil communities, laws of natural, universal and unchangeable obligation hold the first rank: They are such fixed means of union, peace and happiness, that no other can or ought to be substituted in their room. It may however be observed, that the force of civil society cannot extend to all laws of this kind; but only to such upon the observation of which the common quiet of mankind entirely depends. To do to our neighbour as we would that he should do to us is one of the plainest dictates of reason, and a law of universal equity and obligation. It comprehends the whole of social duty, and extends to kindness, humanity and mercy, as well as to truth and justice. But although it is the great rule of our conduct and the bond of society, it cannot in its whole extension have the force of a civil law in commonwealths. Controversies about the violation of it would be perplexed and intricate: Litigious suits would be infinitely multiplied: The good and virtuous would be deprived of the most valuable part of their character: and the state would be tom with intestine division and discord.

But, tho' all the laws of nature cannot be enforced with civil sanctions, yet every righteous state adopts those, which are necessary for the preservation of the public peace, and for an equal and impartial distribution of rewards and punishments.

GOODRICH, supra note 55, at 13-14 (Conn. election sermon 1787) (Evans 20,393). 
all too many individuals did not conform their behavior to natural law, and the reasoning that constituted natural law could not make them do so. ${ }^{97}$ For this reason, civil law not only had to be more detailed and clear than natural law, but it also had to provide sanctions. ${ }^{98}$

Thus, Americans said that they should adopt constitutions and other civil laws that were in accordance with the implications of natural law. Yet typically they distinguished natural law from constitutional law and assumed that the former could not imply the precise content of the latter or, indeed, of any civil law.

\section{The Natural Law Context of Civil LaW Restraints ON NATURAL RIGHTS}

The relationship between natural law and civil law had consequences for the natural rights enjoyed under civil law, including the natural rights protected in constitutions. If natural law was understood to define or restrain natural liberty in the state of nature (as seen in Part III), and if civil laws were understood to reflect the implications of natural law (as observed in Part V), then the imposition of such civil laws did not infringe or, at least, did not diminish natural liberty. As earlier in this Article, the natural right of freedom of speech and press will be used an illustration: if the laws of defamation, obscenity, and fraud reflected the pre-existing natural law limitations on the natural right of speech and press, then they did not violate or abridge that right.

\footnotetext{
An emphasis on the extent to which civil laws could not adequately enforce natural or moral laws typically was employed to justify the establishment of religion. Following Warburton, many establishment ministers argued that natural law or moral obligations were so extensive that civil government and its laws could not sufficiently enforce even the moral obligations necessary for the preservation of government. In particular, they said that civil laws could only regulate the temporal and outwardly visible manifestations of immorality. Like Warburton, they thereby implied the necessity of religion, especially an establishment of religion. Jonathan Edwards, Jr. preached:

Nor does the magistrate pretend to punish vice in general. He does undertake to punish those gross vices, which consist in the violations of the perfect rights of men, and in those cases only, in which the violations are both manifest and are manifestly proved before a proper tribunal. But all violations of even these rights which are perpetrated in private, or which, though perpetrated publicly, are not legally proved, pass entirely free from civil pains and penalties. The same is true of all violations of the imperfect rights, as they are called, which are violated by ingratitude, selfishness, neglect of kind offices, \&c.

JONATHAN EDWARDS, JR., THE NECESSTTY OF THE BELIEF IN CHRISTLANITY (1794), reprinted in POLITICAL SERMONS, supra note 30 , at $1189-90$.

97. Following Pufendorf, Locke and others, Chief Justice Swift of Connecticut wrote that "on actual experiment, it is found that men will not regard the dictates of the moral law, and that individual strength is insufficient to repel the violence of injustice." 1 SWIFT, supra note 60 , at 15; see also JAMES WILSON, Lectures on Law, reprinted in 1 WORKS OF JAMES WLSON, supra note 41, at 143.

98. In this sense, "civil government becomes a substitute for moral virtue." "Republicus," KY. GAZ., Feb. 16, 1788, reprinted in THE COMPLETE ANTI-FEDERALIST, supra note 37, at 160, 162. The aptly named John Devotion preached of "civil institutions" that "are a substitute for lost innocence." JOHN DEVOTION, THE DUTY AND INTEREST OF THE PEOPLE 29 (Conn. election sermon 1777) (Evans 15,285). Coke had written that the municipal laws imposed penalties for breaches of the law of nature because "that law only consisted in commandiug [sic] or prohibiting, without any certain punishment or penalty." Calvin's Case, 77 Eng. Rep. 377, 392 (Ex. Ch. 1608).
} 
The position that civil law did not deny, violate, infringe, abridge, or diminish natural liberty depended upon the notion of a noninjurious or more broadly moral natural liberty defined by natural law. For example, the Reverend Hemmenway had said:

Our natural rights are bounded and determined by the law of nature, which binds us to be subject to the will and authority of God, to love and worship him; to be just and benevolent to our fellow creatures, doing them all the good in our power, and offering no injury or abuse to any one. It is therefore no violation of our natural liberty and rights for us not to be allowed to do wrong, and to be restrained by force and punishments, from invading the right and property of others. ${ }^{99}$

If natural rights were "bounded and determined" by natural law-in other words, if natural liberty was only the right to do nothing contrary to natural law-then civil laws that reflected natural law were "no violation of our natural liberty and rights." This was an attractive proposition, and, indeed, during the late eighteenth century, myriad Americans asserted that government should not and, in America, did not infringe or deny any natural rights. ${ }^{100}$ Similarly, the sometime Chief Justice of Vermont, Nathaniel Chipman, said it was an "agreeable reflection" to suppose that "there is no... opposition between natural and civil rights"; ${ }^{101}$ Americans, he hoped, would attain "the coincidence of natural and civil rights." 102 In a less sophisticated context, a Pennsylvania newspaper pronounced: "Let America for-ever boast, that her subjects freely

99. HEMMENWAY, supra note 61, at 13-14 (Mass. election sermon 1784) (Evans 18,526). See also his statement supra note 86.

100. Thomas Tudor Tucker, a South Carolina doctor and member of the Continental Congress, wrote that "the power of injuring one's neighbor . . . is not a matter of right even in an uncivilized State, and therefore the restraint a man suffers in that respect in society is not to be considered as any abridgement of his natural freedom." "PHILODEMUS" [THOMAS TUDOR TUCKER], CONCILIATORY HINTS, ATTEMPTING, BY A FAIR STATE OF MATTERS, TO REMOVE PARTY PREJUDICE (1784), reprinted in 1 AMERICAN POLITICAL WRITRG, supra note 29 , at 613 . Wilson took a similar position. He defined natural liberty as an individual's right to use his powers "as his inclination and judgment shall direct, provided he does no injury to others; and provided some publick interests do not demand his labours." Wilson then argued:

If this description of natural liberty is a just one, it will teach us, that selfishness and injury are as little countenanced by the law of nature as by the law of man. Positive penalties, indeed, may, by human laws, be annexed to both. But these penalties are a restraint only upon injustice and overweening self-love, not upon the exercise of natural liberty.

JAMES WLSON, Lectures on Law, in 2 WORKS OF JAMES WRSON, supra note 41, at 587; see also William Cushing, Charge to the Grand Jury of the Circuit Court for the District of Rhode Island (Nov. 7, 1794), in 2 DOCUMENTARY HISTORY OF THE SUPREME COURT, supra note 61, at 491. Note also Francis Hutcheson's view that

As natural liberty is 'the right of acting as one inclines, within the bounds of the law of nature;'

... so we say, a people enjoy liberty when 'each one is allowed to act as he inclines, within

the bounds of civil law, and not subjected to the caprice of any other.'

3 HuTCHESON, supra note 41, at 257 (bk. III, ch. vii, § 5).

101. CHIPMAN, SKETCHES, supra note 48 , at $72-73$.

102. Id. at 73. He also wrote: "To this constitution of nature, all civil laws, and political institutions ought to be adapted. This alone can produce and support a coincidence between civil and moral obligation." Id. at 231. 
and fully enjoy liberty and property and all those natural rights which God and nature assigned to them."103 Of course, Americans who expressed such views did not think they were challenging the traditional maxim that some natural freedom was sacrificed to government. Americans apparently tended to understand that one type of liberty was sacrificed to government and the other was not. Speaking of physical natural rights or powers, they asserted the necessity of sacrificing some of their freedom; speaking of noninjurious or moral natural rights, they insisted that government ought never infringe any natural right. $^{104}$

103. PA. PACKET, Aug. 20, 1787, reprinted in 13 DOCUMENTARY HISTORY OF THE CONSTITUTION, supra note 39, at 188. Theophilus Parsons insisted that "no power was given to Congress to infringe on any one of the natural rights of the people by this Constitution; and, should they attempt it without constitutional authority, the act would be a nullity, and could not be enforced." 2 ELLIOT'S DEBATES, supra note 39, at 162 (statement of Theophilus Parsons in Mass. Ratifying Convention). Richard Bland wrote: "Great is the Power of Parliament, but, great as it is, it cannot, constitutionally, deprive the People of their natural Rights." RICHARD BLAND, AN INQUIRY INTO THE RIGHTS OF THE BRIIISH COLONIES (1766), reprinted in 1 AMERICAN POLITICAL WRITING, supra note 29, at 83. Another American preached: "Every privation of their natural rights is subversive of their happiness, and every infringement of the form of their constitution has a tendency to such privation." DANIEL SHUTE, AN ELECTION SERMON (May 25, 1768), reprinted in 1 AMERICAN POLITICAL WRITING, supra note 29, at 131. Such ideas were popularized in the mid-eighteenth century by, among other writings, 3 HUTCHESON, supra note 41, at 253-66 (bk. III, chap. vii); see also HADDOW, supra note 25 , at 25 .

104. Only occasionally did Americans conflate the role of these two types of natural liberty, and when they did, they did so with a sense of their originality. Nathaniel Chipman understood the conventional approach, for he noted that Beccaria "speaks of a sacrifice of that universal liberty of action, common to all sensible beings, and limited only by our natural powers." CHIPMAN, SKETCHES, supra note 48 , at 73. Having described the sacrifice of liberty in the conventional way, however-that is, in terms of the physical natural liberty - Chipman then challenged it:

Man has a natural, that is, a mere physical power, to injure both himself and others. But is a liberty to do this accorded to him by the laws of his nature? that is, a right to do wrong. Power, and liberty, are not of equal extent in signification. Power is, in a strict sense, that, by which we are enabled to exercise our liberty; not the liberty itself, when considered as a right. In a larger sense, it comprehends, both the right, and the power. Civil liberty is generally taken in this sense. It will not be suggested, that liberty and moral obligation are at variance. I think, therefore, it will be more just to say, that, liberty of action, common to sensible beings, is limited by their natural powers, by the obligations of morality, in a word, by the laws of their whole nature. To give up the performance of any action, which is forbidden by the laws of moral and social nature, Id. at 74 . cannot be deemed a sacrifice.

Late in his life, Jefferson similarly denied the commonplace that individuals in the state of nature sacrificed some of their natural liberty to government to preserve the rest: "No man has a natural right to commit aggression on the equal rights of another, .... When the laws have declared and enforced all this, they have fulfilled their functions; and the idea is quite unfounded, that on entering into society we give up any natural right." Letter from Thomas Jefferson to F.W. Gilmer (June 7, 1816), 11 THE WORKS OF THOMAS JEFFERSON, at 534 (Paul L. Ford ed., 1888) [hereinafter JEFFERSON, WoRKs]. Far from having adopted a new vision of society-a society without legal restraints-he had merely come to talk about the formation of society and government in terms of noninjurious or moral natural rights, which were defined rather than limited by natural law. For the varying formulations employed by Jefferson in different circumstances, see infra note 135 .

The truism that men sacrificed some of their liberty to government rested upon the assumption, frequently made explicit, that the liberty given up was the physical freedom or power to do as one pleased without subjugation to others. Chipman and Jefferson, however, incongruously discussed the formation of government in terms of the other, less expansive type of natural freedom-the noninjurious or moral liberty defined by natural law. Having done this, they had no difficulty denying that any natural right was sacrificed. They thereby attempted to confute a traditional maxim of political theory by misstating one of its well-known presuppositions. Of course, it was Jefferson who took this refutation and gave it an unusually dramatic and 
Even when discussing the extensive natural liberty to do as one pleased, Americans could insist that the institution of civil government and civil laws-including some substantial moral and economic regulation-should not and did not abridge or diminish any of their natural freedom. ${ }^{105}$ Nathaniel Chipman wrote that "liberty of action, common to sensible beings, is limited by their natural powers, by the obligations of morality, in a word, by the laws of their whole nature. To give up the performance of any action, which is forbidden by the laws of moral and social nature, cannot be deemed a sacrifice." 106 If physical natural liberty was subject to natural law already in

extreme formulation.

Jefferson's formulation was later used by the Loco-Foco or Equal Rights Party. For example they declared:

That the idea is quite unfounded, that on entering into society we give up any natural right. That the rightful power of all legislation is to declare and enforce only our natural rights and duties, and to take none of them from us. No man has a natural right to commit aggression on the equal rights of another, and this is all from which the law ought to restrain him. Every man is under the natural duty of contributing to the necessities of society; and this is all the law should enforce on him. When the laws have declared and enforced all this, they have fulfilled their functions.

Declaration of Rights, $\$ 3$ in FRANCIS BYRDSALL, THE HISTORY OF THE LOCO-FOCO OR EQUAL RIGHTS PARTY 68 (Burt Franklin ed., 1967) (1842); see also id. at 39, 57-58; DEMOCRATIC EQUAL-RIGHTS PLATFORM, ADOPTED IN THE N.Y. CONVENTION OF 1836, reprinted in AMERICAN STATE PAPERS, supra note 38, at 166-67.

105. During the controversy over ratification of the U.S. Constitution, David Ramsay wrote: In a state of nature, each man is free, and may do what he pleases: but in society, every individual must sacrifice a part of his natural rights; the minority must yield to the majority, and the collective interest must controul particular interests. . . . When several parishes, counties, or districts, form a state, the separate interests of each-must yield to the collective interest of the whole. When several states combine in one government, the same principles must be observed. These relinquishments of natural rights, are not real sacrifices: each person, county, or state, gains more than it loses, for it only gives up a right of injuring others, and obtains in return aid and strength to secure itself in the peaceable enjoyment of all remaining rights.

DAVID RAMSAY, AN ADDRESS TO THE FREEMEN OF SOUTH CAROLINA, ON THE SUBJECT OF THE FEDERAL CONSTITUTION (1788), reprinted in PAMPHLETS, supra note 79, at 373.

106. ChIPMAN, SKETCHES, supra note 48 , at 74. Chipman also said:

Man has a natural, that is, a mere physical power, to injure bnth himself and others. But is a liberty to do this accorded to him by the laws of his nature? that is, a right to do wrong. Power, and liberty, are not of equal extent in signification. Power is, in a strict sense, that, by which we are enabled to exercise our liberty; not the liberty itself, when considered as a right. In a larger sense, it comprehends, both the right, and the power.

Id. at 74. Much later, when discussing religious liberty, Chipman wrote:

To violate the rights of others, to disturb the peace and good order of society under pretence of conscience, or of religious duty are acts equally criminal as though perpetrated under any pretence whatever.-They are equally prohibited by the laws of nature; they are prohibited by the Supreme Being, the Author of religion, and the object of all religious worship, and justly punishable by the laws of society. To punish the abuse, instead of being a restraint upon liberty, is in fact, its greatest surety.

CHIPMAN, PRINCIPLES, supra note 48, at 101.

An analysis based upon assumptions about the physical liberty of individuals in the state of nature may, perhaps, explain some of the language of the First Amendment. The Amendment uses the word "abridge" with respect to the natural rights protected there, except the right of free exercise. Many Americans assumed that the right of free exercise of religion was a natural right that should not be subject to any restraints by civil law. An individual could not submit his conscience with respect to religion to other individuals, and, indeed, the temporal purposes of civil government, argued many Americans, indicated that it had jurisdiction only over temporal matters. Thus, for example, speaking of what he called "Rights of Conscience," the prominent Baptist, Samuel Stillman, noted that "in a state of nature, and of civil society [they] are exactly the same." STILLMAN, supra note 37, at 11 (Mass. election sermon 1779) (Evans 16,537). Similarly, speaking 
the state of nature, and if civil laws reflected natural law, then the imposition of civil laws did not reduce natural liberty.

Americans could use these notions of natural liberty to discuss the circumscribed character of particular natural rights, including the freedom of speech and press. ${ }^{107}$ Sometimes, they spoke of what appears to have been the noninjurious or moral natural liberty of speech and press. For example, in his proposal for a House committee report on the Bill of Rights, Roger Sherman wrote: "The people have certain natural rights which are retained by them when they enter into society. Such are the rights ... of Speaking, writing and publishing their Sentiments with decency and freedom." 108 This right to speak, write, and publish "with decency" was to be retained in society; it was the sort of right that was not to be denied or infringed. Alternatively, Americans described the freedom of speech and press as the physical liberty to say or publish whatever one wanted-this broad natural freedom being restricted by natural law and, under civil government, also by civil law. On this basis, the Reverend Hemmenway of Massachusetts preached that "in a state of natural liberty, every one has a right to be exempt from subjection to the authority of any man. There is also a right to think, speak, and act freely, without compulsion or restraint; and to use our faculties and property as we please, provided that none are thereby injured, nor the obligations of morality infringed." 109 Already

of physical natural liberty, Alexander Addison later contrasted the right of conscience to the right of publication: "The right of conscience is a natural right of a superior order for the exercise of which we are answerable to God. The right of publication is more within the control of civil authority, and was thought a more proper subject of general law." ALEXANDER ADDISON, ANALYSIS OF THE REPORT OF THE COMMITTEE OF THE VIRGINIA ASSEMBLY (1800), reprinted in 2 AMERICAN POLITICAL WRITING, supra note 29, at 1055, 1090. He also wrote that "the liberty of conscience cannot be modified, and the liberty of the press cannot be abridged, by authority of the United States." $2 \mathrm{Id}$. at 1092 .

107. Americans could also use these ideas to discuss the natural right of free exercise of religion, saying that individuals in the state of nature had a right of free exercise but not a right to injure others. Witherspoon said: "The magistrate ought to defend the rights of conscience, and tolerate all in their religious sentiments that are not injurious to their neighbors." WITHERSPOON, supra note 25, at 160 (Lecture XIV). According to Israel Evans:

[W]hen a man adopts such notions as, in their practice, counteract the peace and good order of society, he then perverts and abuses the original Liberty of man; and were he to suffer for thus disturbing the peace of the community, and injuring his fellow-citizens, his punishment would be inflicted not for the exercise of a virtuous principle of conscience, but for violating that universal law of rectitude and benevolence which was intended to prevent one man from injuring another.

EvaNs, supra note 37, at 7 (N.H. election sermon 1791) (Evans 23,358). Later, Chipman said that "[t]he propagation of an opinion which does not result in any acts injurious to society, cannot with justice, be subjected to restraint by human laws." CHIPMAN, PRINCIPLES, supra note 48, at 101. In response to the opinions illustrated here by Witherspoon, Evans and Chipman, Jefferson wrote: "The legitimate powers of government extend to such acts only as are injurious to others. But it does me no injury for my neighbor to say there are twenty gods, or no god. It neither picks my pocket nor breaks my leg." THOMAS JEFFERSON, NOTES ON VIRGINIA (1784), reprinted in JEFFERSON, WRITINGS, supra note 57, at 185, 275 (Query 17).

108. Roger Sherman, Proposed Committee Report (July 21-28, 1789), in CREATING THE BLL OF RIGHTS, supra note 39 , at $266-67$.

109. HEMMENWAY, supra note 61, at 14 (Mass. election sermon 1784) (Evans 18,526). He also said: And they may justly be said to enjoy this their right [of civil liberty], when they are allowed the free use of their natural unalienable rights, the most important of which are, the rights of conscience; and also to speak and act, to use and dispose of their property, to hold and enjoy 
in the state of nature, the extensive physical freedom to speak or publish as one pleased was subject to natural law; presumably, civil laws reflective of natural law did not abridge or reduce it. Moral obligations-or at least the implication against injurious behavior derived from the principles of equal freedom and selfpreservation-pre-existed civil government, and, consequently, the laws of defamation, obscenity, and fraud, which reflected those pre-existing duties, did not diminish or abridge the freedom of speech.

The second of these formulations-that freedom of speech and press was a power to say what one pleased-was particularly useful for discussion of the distinction between post-publication sanctions and prior censorship. Seventeenthcentury theorists had indicated that, in the state of nature, each individual might have a physical freedom to do as he or she pleased but was subject to punishment by other individuals for injuries to those other individuals - that is, for violations of natural law. ${ }^{110}$ For reasons these theorists did not anticipate, ${ }^{111}$ their analysis came to have peculiar resonance for English and American lawyers, who assumed that prior censorship would tend to be arbitrary and who, accordingly, defined the freedom of the press in terms of, among other things, a freedom from prior censorship-a freedom to publish what one pleased, subject to later penalties. ${ }^{112}$ For example, during the 1788 Pennsylvania impeachment

every rightful privilege, without disturbance or controul, in such ways as are not injurious to any, or contrary to the reasonable laws, of that civil body of which they are members. And though such laws as lay the subject under needless and burdensome restraints may justly be accounted an abridgment of liberty, yet no one has any reason to complain that he is denied the liberty of a free citizen, when he is restrained by human laws and penalties, from vice and immorality, and obliged to yield due obedience to civil authority, and observe such ordinances and pay such taxes, as are necessary for the support of govemment, and to maintain the order, peace and welfare of the commonwealth.

Id. at 23-24.

110. For an American example of such analysis, see quotation of Stillman supra note 61.

111. For example, Pufendorf discussed obligations relating to speech, and Locke appears to have written the famnus criticisms of censorship adopted by the House of Commons, but neither philosopher applied the analysis described here to justify the distinction between prior and subsequent restraints. See PUFENDORF, supra note 53, at 457-90 (bk. IV, ch. i); 11 H.C. JouR. 305-06 (April 17, 1695).

112. According to Blackstone:

The liberty of the press is indeed essential to the nature of a free state: but this consists in laying no previous restraints upon publications, and not in freedom from censure for criminal matter when published. Every freeman has an undoubted right to lay what sentiments he pleases before the public: to forbid this, is to destroy the freedom of the press: but if he publishes what is improper, mischievous, or illegal, he must take the consequence of his own temerity. To subject the press to the restrictive power of a licenser, as was formerly done, both before and since the revolution, is to subject all freedom of sentiment to the prejudices of one man, and make him the arbitrary and infallible judge of all controverted points in learning, religion, and government. But to punish (as the law does at present) any dangerous or offensive writings, which, when published, shall on a fair and impartial trial be adjudged of a pernicious tendency, is necessary for the preservation of peace and good order, of govemment and religion, the only solid foundations of civil liberty. Thus the will of individuals is still left free; the abuse only of that free will is the object of legal punishment. Neither is any restraint hereby laid upon freedom of thought or enquiry: liberty of private sentiment is still left; the disseminating, or making public, of bad sentiments, destructive of the ends of society, is the crime which society corrects. ... the press cannot be abused to any bad purpose, without incurring a suitable punishment: whereas it never can be used to any good one, when under the control of an inspector.

4 WILLIAM BLACKSTONE, COMMENTARIES *151-53. 
proceedings against the judges who had presided in the trial of the AntiFederalist printer, Eleazer Oswald, Representative William Lewis (who had been the prosecutor in Oswald's trial) defended the judges on the ground that they had punished an abuse of freedom:

Here, then, is to be discerned the genuine meaning of this [free press] section in the [Pennsylvania] bill of rights .... Every man may publish what he pleases; but, it is at his peril, if he publishes any thing which violates the rights of another, or interrupts the peace and order of society ... ${ }^{113}$

As in the state of nature, Americans had a natural freedom or power to speak and publish as they pleased, but they could be punished if they did so at the expense of the equal rights of others. Whereas in the state of nature, injured individuals sought retribution against one another in accordance with their individual understandings of natural law, under civil government, the state punished injuries, and it did so on the basis of a known rule, the civil law. By embodying the natural law implications or restraints that pre-existed civil government, the civil law left the natural freedom of speech and press undiminished, and, by penalizing rather than preventing injurious language, it employed a means of enforcement that was not likely to be arbitrary.

Whether in terms of physical freedom or noninjurious freedom, Americans often described the freedom of the press in its natural law context. For example, when the 1788 Virginia ratifying convention proposed a bill of rights, it included in its suggestions a guarantee "[t]hat the people have a right to freedom of speech, and of writing and publishing their Sentiments; but the freedom of the press is one of the greatest bulwarks of liberty and ought not to be violated."114 The Virginia convention also proposed, however, "[t]hat every freeman ought to find a certain remedy by recourse to the laws for all injuries and wrongs he

In the Pennsylvania ratifying convention, James Wilson explained that "what is meant by the liberty of the press is, that there should be no antecedent restraint upon it, but that every author is responsible when he attacks the security or welfare of the government or the safety, character, and property of the irdividual." James Wilson, Speech in Pa. Ratifying Convention, in 2 DOCUMENTARY HISTORY OF THE CONSTITUTION, supra note 39 , at 454,455 .

113. Respublica v. Oswald, 1 U.S. (1 Dall.) 319, 329-31 $\mathrm{n}^{*}$ (Pa. 1788) (libel held contempt of court). The Pennsylvania Constitution of 1776 may have referred to the moral natural right: "[T]he people have a right to freedom of speech, and of writing, and publishing their sentiments; therefore the freedom of the press ought not be restrained." PA. CoNST. of 1776, ch. I (Decl. of Rights), $\$ 12$. After Oswald's case and the subsequent accusations against the judges, the Pennsylvania Constitution, when rewritten in 1790, was altered to declare that "The free communication of thoughts and opinions is one of the invaluable rights of man; and every citizen may freely speak, write, and print on any subject, being responsible for the abuse of that liberty." PA. CONST. of 1790 , art. IX, $\$ 7$. Professor Robert Palmer says of this clause that "its very words indicated that the abuse was still an exercise of the liberty: the qualification was really external and not a matter of the very definition of freedom of the press." Palmer, supra note 15, at 55, 128. The qualification, however, was not external in the way Palmer suggests. See id. It appears simply to reflect the natural law limitations on physical natural liberty in the state of nature.

114. Amendments proposed by the Virginia Ratifying Convention (June 27, 1788), § 16, in CREATING THE BILL OF RIGHTS, supra note 39 , at $17,18-19$. 
may receive in his person, property, or character." to an individual's natural rights-to his "person, property, or character"--were to have legal remedies. The Virginia convention apparently assumed that legal remedies for injury to the natural right of reputation or character were in accordance with a constitutional guarantee of the freedom of speech and press. ${ }^{116}$

This analysis of the freedom of speech and press in the context of natural law was frequently employed in subsequent discussion of the U.S. Constitution. For example, in support of the Sedition Act, which created a statutory version of the offense of seditious libel, Congressman Robert Goodloe Harper of South Carolina pointed out that individuals had a physical natural liberty, but that they could be punished if they used it injuriously:

Every man possessed the liberty of action; but if he used this liberty to the detriment of others, by attacking their persons or destroying their property, he became liable to punishment for this licentious abuse of his liberty. The liberty of the press stood on precisely the same footing. Every man might publish what he pleased; but if he abused this liberty so as to publish slanders against his neighbor, or false, scandalous, and malicious libels against the magistrates, or the Government, he became liable to punishment. ${ }^{177}$

On this basis, Harper said he was astonished that the Sedition Act was "called a law abridging the liberty of the press!"”18

Even a passionate critic of the Alien and Sedition Acts, George Hay, could use the natural law context of natural rights, but he was anxious to distinguish, not between prior and subsequent restraints, but rather between injuries to

115. Id. at 18 ( $\$ 12)$. Similarly, the Massachusetts Constitution declared that "[e]very subject of the Commonwealth ought to find a certain remedy, by having recourse to the laws, for all injuries or wrongs which he may receive in his person, property, or character." MASs. CoNsT. of 1780, Decl. of Rights, art. XI. Swift, moreover, wrote that, on "entering into a state of society," mankind "are restricted from injuring each other in person, character, and property." I SWIFT, supra note 60, at 177; see also Benjamin Franklin, An Account of the Supremest Court of Judicature in Pennsylvania, viz., The Court of the Press, FED. GAZ., Feb. 12, 1789, reprinted in 2 AMERICAN POLITCAL WRITING, supra note 29, at 707,710; Jefferson's proposal for a press clause in the Virginia Constitution quoted supra note 83.

116. In the debates about ratification of the U.S. Constitution, the extent of the right of speech and press and its relationship to natural law do not appear to have become matters of discussion; typically, Americans debated whether the Constitution should have enumerated the right, not how the right was understood.

117. 8 ANNALS OF CoNG. 2167-68 (1798).

118. Id. at 2168. When the Virginia and Kentucky legislatures passed resolutions condemning the Alien and Sedition Laws, the Massachusetts legislature responded with its own resolution. Reflecting the common assumption that natural law was a mode of reasoning about the use and preservation of natural liberty, it resolved, among other things, that the "freedom of the press has been explicitly secured by most, if not all the state constitutions; and of this provision there has been generally but one construction among enlightened men-that it is a security for the rational use, and not the abuse of the press. . ." 4 ELLIOT'S DEBATES, supra note 39, at 535 . Thus, American constitutions typically had been understood to permit the "rational use" rather than the "abuse" of the freedom of the press-in other words, they had been understood in terms of the natural law reasoning about natural liberty. 
individuals and injuries to society or government. When interpreting the First Amendment's language about the "freedom" of speech and press, Hay asserted that there were only two possible types of freedom. One was what Blackstone had called "absolute liberty"- that is, natural liberty, or the freedom existing in the state of nature. This was an individual's

power, uncontrolled by law, of doing what [h]e pleases, provided he does no injury to any other individual. If this definition of freedom be applied to the press, as surely it ought to be, the press, if I may personify it, may do whatever it pleases to do, uncontrolled by any law, taking care however, to do no injury to any individual. This injury can only be by slander or defamation, and reparation should be made for it in a state of nature, as well as in society. ${ }^{119}$

This first type of freedom was natural liberty limited by the natural law implication against injury to others. In contrast, argued Hay, was a second type of freedom, the natural liberty permitted by civil law-that is, whatever natural liberty the legislature happened to leave unrestrained by civil laws. ${ }^{120}$ Rejecting the possibility that the freedom of the press referred to by the First Amendment was merely such natural freedom of speaking and publishing as Congress deigned to permit, Hay concluded that the First Amendment's freedom of speech and press "means the power uncontrolled by law, of speaking either truth or falsehood at the discretion of the individual, provided no other individual be injured." 21 Thus, Hay accepted that the "absolute" or natural right of freedom of the press was limited by a duty not to injure other individuals, and he used this definition to distinguish between injury to individuals and injury to government. Whereas some writers claimed that natural law created an implication merely against injury to individuals, other writers had insisted that natural law also concerned injury to government or society as a whole. ${ }^{122} \mathrm{By}$

119. "HORTENSIUS" [GEORGE HAY], supra note 39, at 37-38. Hay also argued that the United States was a government of enumerated powers, and that these powers did not include a press power. Id. at 18-19. In contrast, states had the power to punish "slander." Id. at 19-20.

120.

But freedom in society, or what is called civil liberty, is defined to be, natural liberty, and so far restrained by law as the public good requires and no farther. . . . Now let freedom, under the definition, be applied to the press, and what will the freedom of the press amount to? It will amount precisely to the privilege of publishing, as far as the legislative power shall say, [what] the public good requires. .. If the word freedom was used in this sense, by the framers of the amendment, they meant to say, Congress shall make no law abridging the freedom of the press, Id. at 38 .

which freedom, however, is to be regulated by law. Folly itself does not speak such language.

121. Id. at 40 . Hay began this sentence by talking about "that freedom of speech," but the context reveals that he was not here distinguishing this from freedom of the press.

122. For example, Chief Justice John Jay said that " $[t]$ o restrain men from violating the Rights of Society $\&$ of one another, and impartially to give Security \& Protection to all, are among the most important Objects of a free Government..." John Jay, Charge to the Grand Jury of the Circuit Court for the District of Virginia (May 22, 1793), in 2 DOCUMENTARY HISTORY OF THE SUPREME COURT, supra note 61, at 380, 381. According to the Massachusetts Constitution, "The end of the institution, maintenance and administration of government, is to secure the existence of the body-politic; to protect it; and to furnish the individuals 
deliberately ignoring the possibility that natural law might include implications against injury to society or government, Hay could show that the First Amendment distinguished between press laws that protected individuals and those that protected government. The Amendment, he argued, forbade Congress from enacting the latter. ${ }^{123}$ Hay accepted, however, that the First Amendment right of speech and press was the natural right of speech and press and that this right was limited by the obligation to avoid injury to individuals. ${ }^{124}$

Of course, it is not contested here that Americans frequently discussed the extent of the freedom of speech and press without alluding to ideas of natural liberty or natural law. Sometimes, for example, Americans simply defined the freedom in terms of the common law restraints upon it. Even when Americans talked about the freedom of speech and press as a broader principle or generality, they often distinguished between liberty and license, without clearly alluding to natural rights or natural law. ${ }^{125}$ Yet, when Americans had to provide a more detailed analysis of the freedom of speech and press, they had in their natural rights analysis a means of explaining the limited extent of the constitutional right. ${ }^{126}$

who compose it, with the power of enjoying, in safety and tranquility, their natural rights, and the blessings of life." MASS. CONST. of 1780, pmbl.

123. Similarly, note Jefferson's emphasis on private injury in the press clause he drafted for the Virginia Constitution: "Printing presses shall be free, except so far as by commission of private injury cause may be given of private action." Thomas Jefferson, Fair Copy of the Virginia Constitution, art. IV (June, 1776), in 2 JEFFERSON, WORKS, supra note 104, at 180-81.

124. At the close of his pamphlet, Hay said that "The freedom of the press, therefore, means the total exemption of the press from any kind of legislative control ..." "HORTENSIUS" [GEORGE HAY], supra note 39 , at 50 (Evans 35,605). Earlier, however, he revealed his acceptance of the states' common law relating to slander. Id. at 19-20. Benjamin Oliver-a writer of law books, a noted chess player, and son of a former Govemor of Massachusetts - used the analysis described in the text here to justify federal regulation of libel:

In the first amendment to the constitution, congress is prohibited to pass any law, to abridge the

freedom of speech or of the press. It has never been pretended, that congress has any power to enlarge the natural right, which men have of communicating their sentiments to each other, and consequently this amendment was made merely in order to prevent this natural right from being abridged. When, therefore, the limits of this natural right are once clearly ascertained, no law, though made by congress for the express purpose of punishing those, who overstep the limits of this natural right, will be unconstitutional on the mere ground that it abridges the freedom of speech. For, as it is the natural right which congress is forbidden to abridge, if congress merely punishes those acts which have no authority at all in natural right, the constitution will not be violated. This view of the subject is sufficient to show, that congress is not prohibited by this amendment to the constitution, to enact any laws which they may think proper, to punish libels upon those who are engaged in the administration of the general government. For, no man has any natural right to slander another, by inventing, circulating and publishing malicious falsehoods in relation to his character. Consequently, no natural right is infringed by a law enacted to punish such injuries.

OLIVER, supra note 63 , at 223 . Incidentally, note that, already in 1832 , he fails to mention the absence of an enumerated power authorizing the federal government to regulate the press. See supra note 80.

125. See, e.g., ALEXANDER ADDISON, ANALYSIS OF THE REPORT OF THE COMMTTEE OF THE VIRGINIA ASSEMBLY (1800), reprinted in AMERICAN POLITICAL WRITING, supra note 29, at 1055, 1089, 1093, 1096; Benjamin Franklin, An Account of the Supremest Court of Judicature in Pennsylvania, viz., The Court of the Press, PHILA. FED. GAZ., Feb. 12, 1789, reprinted in 2 AMERICAN POLITICAL WRITING, supra note 29, at 707, 708-09.

126. Eventually, some would renounce this analysis and its limits on speech and press. For example, Representative John Nicholas of Virginia denied that it was possible to distinguish between the liberty and 
Although Americans often discussed constitutional guarantees of natural rights in terms of natural law, they did not broadly incorporate natural law into their constitutions and usually did not question the positive character of these documents. On the contrary. As James Wilson said:

In a state of natural liberty, every one is allowed to act according to his own inclination, provided he transgresses not those limits, which are assigned to him by the law of nature: in a state of civil liberty, he is allowed to act according to his inclination, provided he transgresses not those limits, which are assigned to him by the municipal law. ${ }^{127}$

In other words, only "municipal" or civil laws-including American constitutions ${ }^{128}$-were legally binding under civil government.

Therefore, the role of natural law described here was relatively narrow. Natural law indicated the theoretical limits on the exercise of freedom in the state of nature and, on this account, could be understood to determine the theoretical degree to which civil laws could limit natural rights without denying or abridging them. Thus, if, and only if, a constitution reserved a particular natural right from the government's power, ${ }^{129}$ natural law suggested the degree to which the constitution protected that right, not because natural law was incorporated into the constitution, but because natural rights were understood to be subject to natural law. For example, as has been seen, the Bill of Rights prohibited Congress from abridging the natural right of free speech and press, and natural law could be understood to indicate very generally what was an abridgement of that right. ${ }^{130}$

Yet, far from being a practicable measure for determining which laws accorded with a constitution and which did not, natural law tended to be a theoretical explanation of limitations on natural rights. Although Americans understood natural law to be founded on assumptions about individuals in the state of nature, and although they tended to agree at least on the assumptions about self-preservation and equal liberty, they typically assumed that even these two principles were so vague and general as to leave societies or governments

the licentiousness of the press. 8 ANNALS OF CONG. 2140 (1798); see also statements of Webster and Hamilton, supra note 82.

127. JAMES WILSON, Lectures on Law, reprinted in 2 WORKS OF JAMES WILSON, supra note 41, at 587.

128. According to Wilson, "the constitutions of the United States and of the individual states, form a capital part of their municipal law." 2 ld. at 125.

129. In contrast, the U.S. Constitution protected unenumerated natural rights only to the extent it did not grant power over those rights to the federal government. See Hamburger, supra note 80.

130. Of course, even in theory, natural law was not necessarily the only indication of what was an abridgement of the constitutional right, because a constitution might enumerate a natural right but qualify or supplement its protection of the right. The First Amendment right of free speech and press, for example, was understood to preclude prepublication censorship. As seen above, this preference for postpublication restraints was highly compatible with the notion of a physical natural right, but it was not claimed to be derived from natural rights analysis. 
much discretion in choosing which particular laws were appropriate. For example, Americans frequently assumed that their restraints on speech and press-including the laws of defamation, fraud, and obscenity - comported with natural law and therefore did not abridge or diminish the freedom of speech and press. ${ }^{131}$ They hardly claimed, however, that natural law dictated the details of these common law restraints. They typically treated natural law not as an indication of what specific restraints could be adopted, but rather as a general justification for their restraints on the injurious use of natural liberty. Thus, without determining in practice what constituted an abridgement of natural liberty, natural law could, nonetheless, suggest that the civil laws regulating constitutionally-enumerated natural rights were not necessarily unconstitutional. Natural law provided late eighteenth-century Americans with a theoretical explanation of how their legal limitations on the freedom of speech and press and on other natural rights could conform to the constitutional guarantees of those rights.

\section{CONCLUSION}

Natural liberty and natural law were ideas that informed American perceptions of the rights protected by their written constitutions. This is not to say that framers and ratifiers regularly paused during their deliberations to specify the detailed theoretical assumptions examined here, or that they did not also have other theoretical assumptions; rather, it suggests that they and other Americans tended to discuss rights, particularly those guaranteed by written constitutions, in the context of their contemporary theoretical analysis of natural rights. As Nathaniel Chipman wrote,

In the United States of America, political opinions, though considered as merely theoretical, cannot be wholly inconsequential. In these States, government is, professedly, founded in the rights of man. . . . The opinions entertained of government, of the necessity of laws, of the end to be attained by them, and the means of attaining that end, will have an influence on the sentiments of the people, and the reasonings of the legislator. ${ }^{132}$

131. Even this assumption was occasionally challenged but not with much frequency or prominence until 1798.

132. CHIPMAN, SKETCHES, supra note 48 , at 16 . Although the natural rights analysis Chipman observed in so many state constitutions did not appear in the preamble to the U.S. Constitution, it had been recognized as a theoretical foundation of the U.S. Constitution. In a letter in which he formally submitted the Constitution to Congress in September 1787, George Washington acknowledged, in language drawn directly from the standard eighteenth-century natural rights analysis, the difficulties of drafting the document:

Individuals entering into society, must give up a share of liberty to preserve the rest. The magnitude of the sacrifice must depend as well on situation and circumstance, as on the object to be obtained. It is at all times difficult to draw with precision the line between those rights which must be surrendered, and those which may be reserved .... 
These "theoretical" opinions about "the rights of man"- that is, about natural rights-were, indeed, influential; such opinions provided some of the most widely-held and important theoretical assumptions upon which Americans wrote and ratified their constitutions, including their constitutional guarantees of natural rights.

As seen above, the constitutional implications of the natural rights analysis were striking, for the eighteenth-century American analysis of natural rights did not suggest the existence of expansive rights without substantial restrictions. When Americans said that certain rights were natural and pre-existed civil government, they were not thereby indicating that these rights were unlimited. On the contrary, Americans distinguished between natural rights and acquired rights; they assumed that, in the state of nature, natural rights were subject to the implications of natural law; and they assumed that under civil government natural rights were subject to civil laws. Moreover, natural law could be understood to suggest very imprecisely whether a civil law denied or abridged a natural right-a question that carried particular significance if the natural right was enumerated in a constitution.

By examining the American analysis of these limits on the extent of natural rights, we can learn not only about the circumscribed definition of natural rights, but also about the way Americans reconciled their claims of natural rights and natural law with their relatively restrictive civil laws. Contrary to the assumptions of many modern scholars, natural rights and natural law typically were considered compatible with the notion of a written constitution. Americans usually assumed that the people sacrificed some of their natural rights-that is, some of their natural freedom-in order to preserve the remainder, and these Americans understood written constitutions to be documents in which the extent of the sacrifice was recorded. Natural law was not a residual source of constitutional rights but rather was the reasoning that implied the necessity of sacrificing natural liberty to government in a written constitution. Americans tended to assume that natural rights and natural law were ideas that explained and justified written constitutions. ${ }^{133}$

\footnotetext{
Letter from George Washington to the President of Congress, in 1 DOCUMENTARY History OF THE CONSTITUTION, supra note 39 , at 305 . The reasons for omitting a preamble discussing natural rights were explained in a document of the Committee of Detail. See supra text accompanying note 84.

133. Later this would change. Discontented with their written constitutions and the laws produced by the political process, some Americans later developed the natural rights analysis in a way that transformed its constitutional implications. According to eighteenth-century Americans, natural law reasoning suggested that constitutions and other civil laws should be crafted in accordance with natural law. To this unremarkable eighteenth-century analysis, some nineteenth-century Americans brought two important assumptions that had not previously been common: that the implications of natural law were relatively clear and that individuals rather than the people as a whole could be the judges of those implications. These were assumptions that, when pursued with religious fervor, had heady consequences. For instance, a New Yorker who advocated a relatively limited role for government desired that "the laws shall be merely declaratory of natural rights and natural wrongs, and that whatever is indifferent to the laws of nature shall be left unnoticed by human legislation." "A Phrenologist," On Rights and Government, in 9 U.S. MAG. \& DEM. REV., Nov. 1841, at 459,461 (Nov. 1841) (first of two installments with same title). In stronger language, he wrote:
} 
No less important, the natural law constraints on natural rights explained how natural rights could be regulated without being infringed. We frequently differentiate "mere regulation" from other restrictions, and we often assume that we must do so with little historical guidance about the definition of "mere regulation." Far from being indifferent to this problem, however, early Americans often took for granted a solution based on natural law. If, in the state of nature, the liberty of individuals was subject to natural law, then civil laws in accordance with natural law did not abridge or deny any natural rights. Thus, natural law

If the law forbid that which nature allows, it restrains human liberty. If it enjoin a duty which nature does not impose, it inflicts an act of tyranny upon man. If it confer a right which nature has not ordained, it robs some one or many of that which it confers, and works injustice among men.

Id. An example was "where the law gives the goods of the wife instantly upon the marriage to the husband." Id. Later, he said:

Written constitutions are often regarded with ... profound reverence.... The people are taught that they are sacred and inviolable. .. . This is well, if those constitutions are well; otherwise not. So that the first exhortation should be to bring the written constitution to the test of the natural laws, to compare the constitution of government with the constitution of man, and see whether the former is founded upon the latter.

"A Phrenologist," On Rights and Government, 9 U.S. MAG. \& DEM. REV., Dec. 1841, at 568, 573 (second of two installments with same title). Similarly, an opponent of slavery argued:

The laws of nature have their own vindication in their own code, and execute themselves by punishing transgression and rewarding obedience. This vindication sometimes requires the aid of society to bring it into effective operation. There is a vindication in the laws of nature against all evil. Society and government should exhibit this vindication and bring it into exercise; they should act as aids or agents, and be subservient to the laws of nature, and in strict conformity thereto.

Elias E. EllmakeR, THE REVElation OF RIGHTS 23 (1841). Like the "Phrenologist," he argued that "Ig]ovemments attempt to increase the rights of some men, by giving them power over the natural rights of others-by depredations on their industry, property, and lives. Any increase of rights must be the commission of sin; any decrease, a violation of the order of God." Id. at $46-47 \mathrm{n}^{*}$. On this ground, slavery violated natural law, for "[t]he slaveholder adds to himself by taking largely from the African." Id. He went on to ask whether, "[i]f a juror belives an establishment, a regulation, or a law, made by society or government, to be wrong, unjust, or wicked; ought he to give a verdict which will operate unjustly?" Id. at 99. Lysander Spooner was in some respects the most important exponent of this perspective. He wrote:

This rule, principle, obligation or requirement of natural justice, has its origin in the natural rights of individuals, results necessarily from them, keeps them ever in view as its end and purpose, secures their enjoyment, and forbids their violation. It also secures all those acquisitions of property, privilege and claim, which men have natural right to make by labor and contract.

LYSANDER SPOONER, THE UNCONSTITUTIONALTY OF SLAVERY 6 (2d ed. 1860). Then he argued about natural law that, "being the paramount law, it is necessarily the only law: for, being applicable to every possible case that can arise touching the rights of men, any other principle or rule, that should arbitrarily be applied to those rights, would necessarily conflict with it.... Consequently, there is, and can be, correctly speaking, no law but natural law." Id. at 7. Spooner concluded that "natural law tries the contract of government, and declares it lawful or unlawful, obligatory or invalid, by the same rules by which it tries all other contracts between man and man." Id. at 8 . In other words:

IClonstitutional law, under any form of government, consists only of those principles of the written constitution, that are consistent with natural law, and man's natural rights; and that any other principles, that may be expressed by the letter of any constitution, are void and not law, and all judicial tribunals are bound to declare them so.

Id. at 14. Spooner could derive these extraordinary conclusions because he had adapted the natural rights analysis to suit his needs. As he explained in a later justification of his argument, he "assume[d], what is true, that natural law is a thing certain in itself; also that it is capable of being learned." Id. at 137. 
provided a theoretical explanation of how the laws of civil government could regulate natural rights without infringing or diminishing them. ${ }^{134}$

Most dramatically, the account of natural liberty presented here can help us understand what might otherwise appear to be contradictions or paradoxes in constitutional law. For example, Jefferson said both that natural rights were sacrificed to civil society and that no natural rights were sacrificed to civil society. ${ }^{135}$ Theophilus Parsons similarly seemed to contradict himself. In the Massachusetts ratification convention, when Parsons sought to assure his fellow delegates about the extent of Congressional power, he pointed out that Congress could not infringe any natural right not already restrained by the Massachusetts legislature: "Is there a single natural right we enjoy, uncontrolled by our own legislature, that Congress can infringe? Not one."136 By implication, the natural rights that Congress could infringe were rights that in any case were subject to control by the government of Massachusetts. Shortly afterward, however, he argued that "no power was given to Congress to infringe on any one of the natural rights of the people."137 Are we to suppose that a man almost as systematic and elegant in his law as in his mathematics was being so obviously sloppy or inconsistent? As has been seen, not only Jefferson and Parsons but also many other Americans talked about different types of natural right: physical freedom and noninjurious freedom-more precisely, the liberty natural law restrained and the liberty it defined.

Among the constitutional paradoxes in need of explanation are those involving particular natural rights enumerated in the Bill of Rights, such as the freedom of speech and press; and here, as earlier, the freedom of speech and press is the illustration upon which this Article focuses. ${ }^{138}$ How could

134. The analysis also supplied a definition of injury. See supra text accompanying notes 61-62.

135. Jefferson wrote that "our rulers can have no authority over such natural rights only as we have submitted to them." THOMAS JEFFERSON, NOTES ON THE STATE OF VIRGNIA in JEFFERSON, WRITINGS, supra note 57, at 274-75 (Query 17). That Jefferson assumed some natural rights were sacrificed to govemment is also apparent from a 1790 opinion. There, he wrote of the right of adjoumment: "It is a natural right, and, like all other natural rights, may be abridged or regulated in it's exercise by law ...." Thomas Jefferson, Opinion on the Constitutionality of the Residence Bill, in JEFFERSON, PAPERS, supra note 83, at 194, 197.

In contrast, Jefferson later wrote: "No man has a natural right to commit aggression on the equal rights of another; .... When the laws have declared and enforced all this, they have fulfilled their functions, and the idea is quite unfounded, that on entering into society we give up any natural right." Letter from Thomas Jefferson to F.W. Gilmer (June 7, 1816), in 11 JEFFERSON, WORKS, supra note 104, at 534.

136. 2 ELLIOT'S DEBATES, supra note 39, at 93 (statement of Theophilus Parsons in Mass. Ratification Convention).

137. 2Id. at 162 . Then he added: "Should they attempt it without constitutional authority the act would be a nullity, and could not be enforced." 2 Id.

138. The natural rights analysis of injury was significant not only for the freedom of speech and press but also for other natural rights. For example, consider the right of property, to which the U.S. Bill of Rights referred only indirectly by prohibiting takings without compensation. Both the distinction between natural rights and acquired rights and the definition of injury in terms of the equal natural rights of others are suggestive.

The implications also reached what we would call international law. Speaking of a pirate, Wilson told a grand jury:

He has abandoned himself to a savage state of nature. The consequence is, that, by the laws of self-defence, every community has a right to inflict upon him that punishment, which, in a state 
eighteenth-century Americans profess a right of freedom of speech and press and yet not reject as unconstitutional the hiring and firing of public employees for their political opinions? How could they assert the right of free speech and press while accepting the various laws relating to seditious libel, personal defamation, and obscenity? Eighteenth-century Americans recognized that an individual in the state of nature had a freedom to say and publish what he pleased. Yet they also assumed that natural rights were distinct from acquired rights-that rights existing in the state of nature were different from those existing only under civil government-and that therefore the freedom of speech and press did not include, for example, a right to retain government employment. Moreover, Americans assumed that, already in the state of nature, natural law restricted an individual's freedom to say and publish what he pleased and defined the individual's noninjurious or, more broadly, moral natural right of speech and press. Consequently, civil laws that reflected the natural law limitations neither abridged the physical right nor denied the moral right to speak or publish.

Our perception that late eighteenth-century Americans held contradictory views about the natural right of free speech is related to our perception of such contradictions in our own law. We now have forgotten the natural rights and natural law context of free speech and tend to perceive the "principle" or "generality" of speech to be merely the right to speak as one pleases. Therefore, we see contradictions between that generality and the restraints upon it. ${ }^{139}$ Indeed, appreciating that a denial of an acquired right can affect speech as much as can a government restraint, many of us assume that, under the First Amendment, government ought not to be able to take our opinions into account when distributing or denying some of what used to be called "acquired" rights. ${ }^{140}$ In these ways, the seemingly inexorable logic of a claim to speak as one pleases has undermined much of the law of defamation and obscenity and has even precluded speech-based denials of some acquired rights. ${ }^{141}$ Hence, Professor Meiklejohn's paradox..$^{142}$

From this modern perspective, we are apt to perceive the Framers and ratifiers as men who did not fully understand the import of their words, and we find it easy to justify modern First Amendment developments as an elaboration or generalization of the old ideas or principles earlier generations pursued less open-mindedly or systematically than have we. ${ }^{143}$ This is, howev-

of nature, every individual would be entitled to inflict for any invasion of his person or personal property.

James Wilson, Charge to the Grand Jury of the Circuit Court for the District of Virginia (May 23, 1791), in 2 DOCUMENTARY HISTORY OF THE SUPREME COURT, supra note 61, at 166, 178.

139. See supra notes 17 \& 18 .

140. See supra note 20 and accompanying text.

141. For some of the relevant cases, see supra notes $19 \& 20$.

142. See supra note 17 and accompanying text.

143. For example, after noting that eighteenth-century Americans accepted the constitutionality of libel proceedings by public officials, Zechariah Chafee concluded: "The truth is, I think, that the framers had no very clear idea as to what they meant by 'the freedom of speech or of the press'...." Zechariah Chafee 
er, a perspective that may be questioned. After an examination of the ideas of natural liberty and natural law, the late eighteenth-century understanding of freedom of speech and press no longer seems necessarily unsystematic or arbitrary, and late eighteenth-century Americans no longer appear to have been as unmindful of the import of their words as has been claimed. The late eighteenth-century understanding of freedom of speech and press was relatively consistent and systematic within its late eighteenth-century intellectual context.

Jr., Alexander Meiklejohn's Free Speech: And Its Relation to Self-Government, 62 HARV. L. REV. 891,898 (1949) (book review). According to David A. Anderson, "They may not have been sophisticated enough to realize that true freedom of expression must include freedom for even the most dangerous ideas, but they had seen the connection between press criticism and political change." Anderson, supra note 14, at 535-37; see also LEONARD W. LEVY, LEGACY OF SUPPRESSION 224, 247-48 (1960); Melville B. Nimmer, Introduction-Is Freedom of the Press a Redundancy: What Does it Add to Freedom of Speech?, 26 HASTINGS L.J. 639, 641 (1975). The most charitable version of this approach acknowledges that we too suffer from an inevitable failure of perception. Thus, Professor Meiklejohn has written that "like most revolutionaries, the Framers could not foresee the specific issues which would arise as their 'novel idea' exercised its dominion over the governing activities of a rapidly developing nation in a rapidly and fundamentally changing world. In that sense, the Framers did not know what they were doing. And in the same sense, it is still true that, after two centuries of experience, we do not know what they were doing, or what we ourselves are now doing." Meiklejohn, Absolute, supra note 8 at 246, 264. From such a general and generous observation, we should hesitate to dissent. And yet a caveat must be added: Meiklejohn's focus on what the Framers and ratifiers could not have understood obscures the degree to which they were far from unknowing. 